\title{
A record of late Quaternary vegetation and climate change from Woods Lake, Seymour Inlet, coastal British Columbia, Canada
}

by

\section{Susann Stolze}

A thesis submitted to the Faculty of Graduate Studies and Research in partial fulfillment of the requirements for the degree of

Master of Science

Department of Earth Sciences and Ottawa-Carleton Geoscience Center

\author{
Carleton University \\ Ottawa, Ontario \\ April 29, 2004 \\ (C) copyright \\ 2004, Susann Stolze
}




$\begin{array}{ll}\begin{array}{l}\text { Library and } \\ \text { Archives Canada }\end{array} & \begin{array}{l}\text { Bibliothèque et } \\ \text { Archives Canada }\end{array} \\ \begin{array}{l}\text { Published Heritage } \\ \text { Branch }\end{array} & \begin{array}{l}\text { Direction du } \\ \text { Patrimoine de l'édition }\end{array} \\ \begin{array}{l}\text { 395 Wellington Street } \\ \text { Ottawa ON K1A 0N4 }\end{array} & \begin{array}{l}\text { 395, rue Wellington } \\ \text { Ottawa ON K1A ON4 } \\ \text { Canada }\end{array} \\ \end{array}$

Your file Votre référence ISBN: 0-612-97483-9

Ourfile Notre référence ISBN: 0-612-97483-9

The author has granted a nonexclusive license allowing the Library and Archives Canada to reproduce, loan, distribute or sell copies of this thesis in microform, paper or electronic formats.

The author retains ownership of the copyright in this thesis. Neither the thesis nor substantial extracts from it may be printed or otherwise reproduced without the author's permission.
L'auteur a accordé une licence non exclusive permettant à la Bibliothèque et Archives Canada de reproduire, prêter, distribuer ou vendre des copies de cette thèse sous la forme de microfiche/film, de reproduction sur papier ou sur format électronique.

L'auteur conserve la propriété du droit d'auteur qui protège cette thèse. $\mathrm{Ni}$ la thèse ni des extraits substantiels de celle-ci ne doivent être imprimés ou aturement reproduits sans son autorisation.
In compliance with the Canadian Privacy Act some supporting forms may have been removed from this thesis.

While these forms may be included in the document page count, their removal does not represent any loss of content from the thesis.
Conformément à la loi canadienne sur la protection de la vie privée, quelques formulaires secondaires ont été enlevés de cette thèse.

Bien que ces formulaires aient inclus dans la pagination, il n'y aura aucun contenu manquant. 
PAGINATION ERROR.

IEXI COMPLEIE.
ERREUR DE RAGINATION.

LE TEXTE EST COMPLET. 


\begin{abstract}
Late Quaternary vegetation and environmental history were studied from a lake basin infill in an unexplored area of Seymour Inlet, central coastal British Columbia. Pinus dominated the vegetation of the early late glacial, with a cool and moist climate, which terminated by $11,820 \pm 90{ }^{14} \mathrm{C}$ years $\mathrm{BP}$. The late late glacial, characterised by a mixed coniferous forest, showed slightly warmer but still cool conditions and increased moisture, interrupted by a warmer and drier interval. Alnus, Picea and Pteridium aquilinum dominated the vegetation of the early Holocene. Warmer and drier conditions prevailed in this phase, which was interrupted by an interval of cool and moist conditions. Increased moisture and decreased temperatures characterised the mid-Holocene, during which time Cupressaceae, Alnus, Tsuga heterophylla and Picea achieved dominance in regional forests. This represented a transitional stage to the late-Holocene CupressaceaeTsuga heterophylla-(Alnus) phase when modern climate under cool and moist conditions became established. The lithological and microfossil records indicate two marine inundations of the basin in the early late glacial and the late Holocene due to changes in relative sea level.
\end{abstract}

Keywords: Pollen analysis, Holocene, vegetation history, paleoclimate, relative sea level change, British Columbia 
Abstract

Acknowledgements

List of Tables vii

List of Figures $\quad$ viii

List of Abbreviations $\quad x$

1 Introduction 1

2 Study area 3

3 Methods $\quad 7$

3.1 Lake selection 7

3.2 Core sampling and analyses 7

3.3 Pollen preparation 10

3.4 Palynomorph identification and nomenclature 10

3.5 Calculation and data presentation $\quad 12$

3.6 Radiocarbon dates 13

4 Results $\quad 15$

4.1 Pollen assemblage zones 15

4.2 Other palynomorphs 28

5 Discussion 31

$5.1 \quad$ Vegetation and environmental history 31

5.2 Summary of environmental changes 53

5.3 Chronology 56

5.4 Regional synthesis 59

6 Conclusion $\quad 64$ 


\section{Acknowledgements}

I thank H. Roe, C. Doherty, M. Pisaric, R. Mathewes and R.T. Patterson for helpful comments. Critical review of the manuscript was done by H. Roe and R.T. Patterson. Thanks to the Museum of Nature (Ottawa) for providing facilities to conduct pollen analytical research and D. Carter for drafting. Core sampling was done by H. Roe, C. Doherty and R.T. Patterson. A grant from the International Council for Canadian Studies to the author and from the CFCAS (Canadian Foundation for Climate and Atmospheric Studies) to R.T. Patterson made this study possible. 


\section{List of Tables}

Table 3-1 AMS radiocarbon dates for the Woods Lake sediment core.

14

Table 5-1 Summary of late Quaternary vegetation, climate, lake condition and relative sea level changes at the Woods Lake study site. 55

Table 5-2 Comparison of late Quaternary climate changes at selected palynological sites along the Pacific Northwest coast of British Columbia. 63 


\section{List of Figures}

Figure 2-1 Location of study area and sampling site. ........................... 5

Figure 3-1 Diagram and sub-bottom profile of Woods Lake. 9

Figure 4-1 Dendrogram from constrained sum of squares cluster analysis 16

Figure 4-2 Detailed sedimentological overview of the Woods Lake core.

Figure 4-3 Woods Lake - Summarised percentage diagram of the pollen and spores

included in the terrestrial pollen sum. 24

Figure 4-4 Woods Lake - Summarised percentage diagram of the pollen not included in the terrestrial pollen and spore sum. 25

Figure 4-5 Woods Lake - Summarised concentration diagram of arboreal pollen types.

Figure 4-6 Woods Lake - Summarised concentration diagram of non-arboreal pollen and spore types. 27

Figure 4-7 Woods Lake - Other palynomorphs diagram. 30 
Figure 5-1 Topography of the study area, sedimentary infill of Woods Lake and relative sea level. 36 


\section{List of Abbreviations}

$\begin{array}{ll}\text { AP } & \text { Arboreal pollen } \\ \text { BP } & \text { Before present } \\ \text { CWH } & \text { Coastal Western Hemlock } \\ \text { NAP } & \text { Non-arboreal pollen } \\ \text { N/A } & \text { Not applicable } \\ \text { PAZ } & \text { Pollen assemblage zone }\end{array}$




\section{Introduction}

Previous research on the late Quaternary vegetation history of coastal British Columbia has primarily concentrated on the more accessible areas of Vancouver Island (e.g., Hansen, 1950; Hebda, 1983; Heusser, 1983; Pellatt et al., 2001; Brown and Hebda, 2003), the Queen Charlotte Islands (e.g., Pellatt and Mathewes, 1997), the southern mainland coast (Mathewes, 1973) and the northwestern mainland region (Spooner et al., 1997; Cwynar, 1993; Miller and Anderson, 1974). Of particular interest are several larger scale regional research studies on the vegetation history of coastal British Columbia (Lacourse et al., 2003) and the greater Pacific Northwest region of North America (Heusser, C.J., 1985; Brown and Hebda, 2003). These studies have shown that regional climate has oscillated considerably throughout the late Quaternary. The oscillations include: (i) an interval of cooler and drier conditions than present during the late Pleistocene (Brown and Hebda, 2003); (ii) a period of warmer and drier conditions than present during the early Holocene (Pellatt and Mathewes, 1997); (iii) a subsequent interval of warmer and wetter conditions in the mid-Holocene, which is less well documented (Pellatt and Mathewes, 1997); and (iv) cool and moist conditions for the late Holocene (Pellatt and Mathewes, 1997; Brown and Hebda, 2003). Although there appears to be intra-regional variability in the response of vegetation to climatic change, the overall pattern has been consistent through the Holocene (Pellatt and Mathewes, 1997; Brown and Hebda, 2003). 
This study is a palynological investigation of a sediment core from a small lake basin, 'Woods Lake', in the Seymour Inlet complex on the central mainland coast of British Columbia. This lies between Queen Charlotte Islands and Vancouver Island (Figure 2-1). Steep-sided fjords characterise this remote and generally unpopulated area. This research is part of an interdisciplinary project, which aims to analyse high-resolution Holocene paleoclimatic, paleoceanographic, and sea level records from small lakes and anoxic marine basins along the British Columbia coast. For this study, pollen, spores and other palynomorphs were identified to reconstruct the vegetation history and document changes in paleoclimate in this area.

The aim of this research is to provide a greater understanding of the vegetation and climate history of this previously unstudied area of central coastal British Columbia and to correlate the results with palynological records from other sites within the Seymour Inlet complex, and the more intensively investigated areas on Vancouver Island, the Queen Charlotte Islands, and the northern and southern coasts of mainland British Columbia. 


\section{$2 \quad$ Study area}

This study focuses on Woods Lake, which is located in the Seymour Inlet complex on the central mainland coast of British Columbia, about $40 \mathrm{~km}$ northeast of Port Hardy, Vancouver Island (Figure 2-1). Woods Lake (51 00’16.0 N; 127 16’ 07.6 E) is a small, elongated freshwater lake, which lies approximately $30 \mathrm{~m}$ south from the shoreline of Seymour Inlet. The maximum measured water depth is $5 \mathrm{~m}$, maximum length is $100 \mathrm{~m}$ and maximum width is $50 \mathrm{~m}$ (Figure 3-1). The lake drains through an outlet in the northwest. The proximity to the shore was an important factor for logistical and sampling reasons. More remote sites were less accessible due to a dense forest understorey and time constraints.

\section{Environmental settings}

The Seymour Inlet complex comprises a network of islands and glacially scored, steep-sided fjords, which are characteristic of the mainland coast north of Vancouver Island (Pojar and Mackinnon, 1994). The coastal landscape of this mountainous terrain consists of granitic and volcanic rocks of Mesozoic age (Patterson et al., submitted), which have been extensively modified by glacial scouring (Klinka et al., 1996). The soils in the area are generally acidic, being principally derived from the granitic rocks, although there are localised pockets of more well-developed soils resulting from the breakdown of sedimentary material (colluvium) (cf. Pojar and Mackinnon, 1994). 
The Seymour Inlet complex lies within the Coastal Western Hemlock (CWH) biogeoclimatic zone (cf. Hebda, 1995). The CWH zone stretches from low to middle elevation along the British Columbia coast, mostly west of the Coast Mountains (Pojar et al., 1991). Dominant trees include western hemlock (Tsuga heterophylla) and Pacific silver fir (Abies amabilis). Drier areas of the zone are characterised by Douglas-fir (Pseudotsuga menziesii), whereas western red cedar (Thuja plicata) and Sitka spruce (Picea sitchensis) are found in moister parts (Hebda, 1995). 


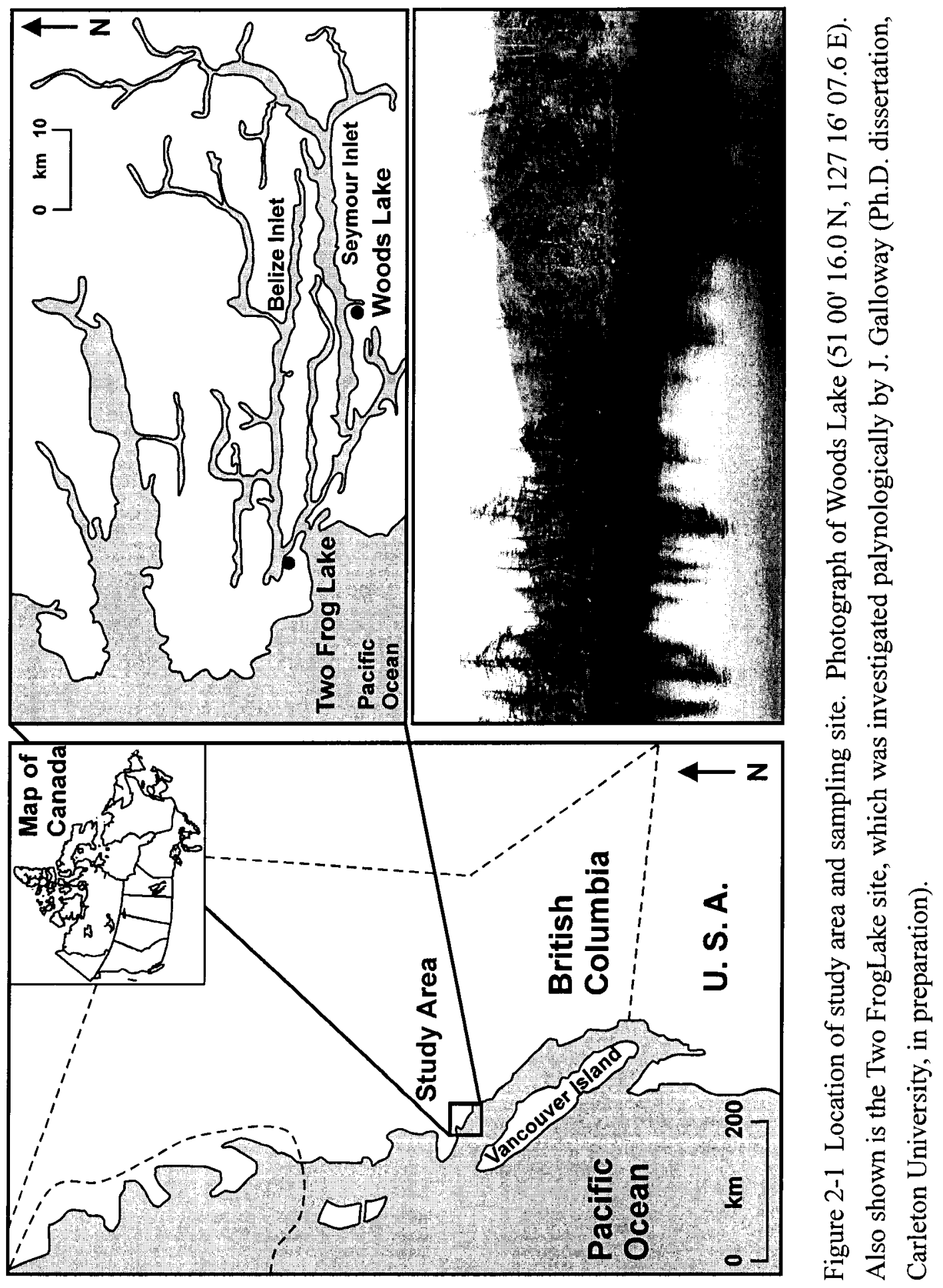


In some coastal areas, the ericaceous shrub Salal (Gaultheria shallon) forms impenetrable thickets in the understorey of the coniferous forests (Pojar and Mackinnon, 1994). The temperate rain forest vegetation surrounding Woods Lake is consistent with the general CWH biogeoclimatic zone distribution, consisting primarily of $T$. heterophylla, P. sitchensis, and T. plicata and the ubiquitous G. shallon in the understorey. Grasses (Poaceae), sedges (Cyperaceae) and G. shallon grow commonly around the lakeshore, whilst Labrador tea (Ledum groenlandicum) and mosses occur intermittently.

The CWH biogeoclimatic zone is characterised by a wet, cool, mesothermal climate (Klinka et al., 1996) with cool summers and mild winters (Meidinger and Pojar, 1991). Mean annual precipitation averages $2228 \mathrm{~mm}$ (1000 to $4400 \mathrm{~mm}$ ) and mean annual temperature is ca. $8^{\circ} \mathrm{C}$ (Meidinger and Pojar, 1991). These conditions are primarily the result of variation in atmospheric and oceanic circulation in the northeast Pacific (Patterson et al., submitted), which are governed by the Aleutian Low, the North Pacific High, the Jet Stream, and the equatorial El Niño/La Niña cycle (Patterson et al., 2000). 


\section{Methods}

\subsection{Lake selection}

Prior to sampling the lakes, potential target lakes were selected from maps and aerial photographs according to accessibility, proximity to the coastline and elevation (less than $10 \mathrm{~m}$ above present sea level). Lake elevation was an important criterion in determining which lakes were to be examined, as examination of a series of lakes with different sill heights would permit accurate tracking of late Quaternary sea level changes using lithology, diatoms, foraminifera and thecamoebians (C. Doherty, Ph.D. dissertation, Queen's University of Belfast, in preparation). Accessibility was a key factor, as rough terrain and clearing Gaultheria shallon often made overland access to the lakes extremely difficult. Woods Lake was one of only three lakes, out of 30 potential lakes originally selected, which were ultimately visited and cored. Most of the lakes were determined to be inaccessible.

\subsection{Core sampling and analyses}

Lake depth and the nature of the sedimentary infill were first determined using a sub-bottom profiler. This provided a useful means of establishing the best location to obtain a continuous sediment core of optimal thickness through the infill sequence. A sediment core of $282 \mathrm{~cm}$ in length was obtained in April 18, 2002 with the aid of a Livingstone corer from a raft moored in the deepest part of the lake. The sediment core 
was refrigerated on board the CCGS Vector, and extruded within a few days on return to the Pacific Geosciences Centre, Vancouver Island. The core was split, photographed, logged, X-rayed and subsequently cut into $1 \mathrm{~cm}^{3}$ aliquots for sedimentological (loss-onignition, particle size) and microfossil (diatom, thecamoebian, foraminiferal and pollen) analyses. Samples for radiocarbon dating were collected at notable sedimentary contacts. 


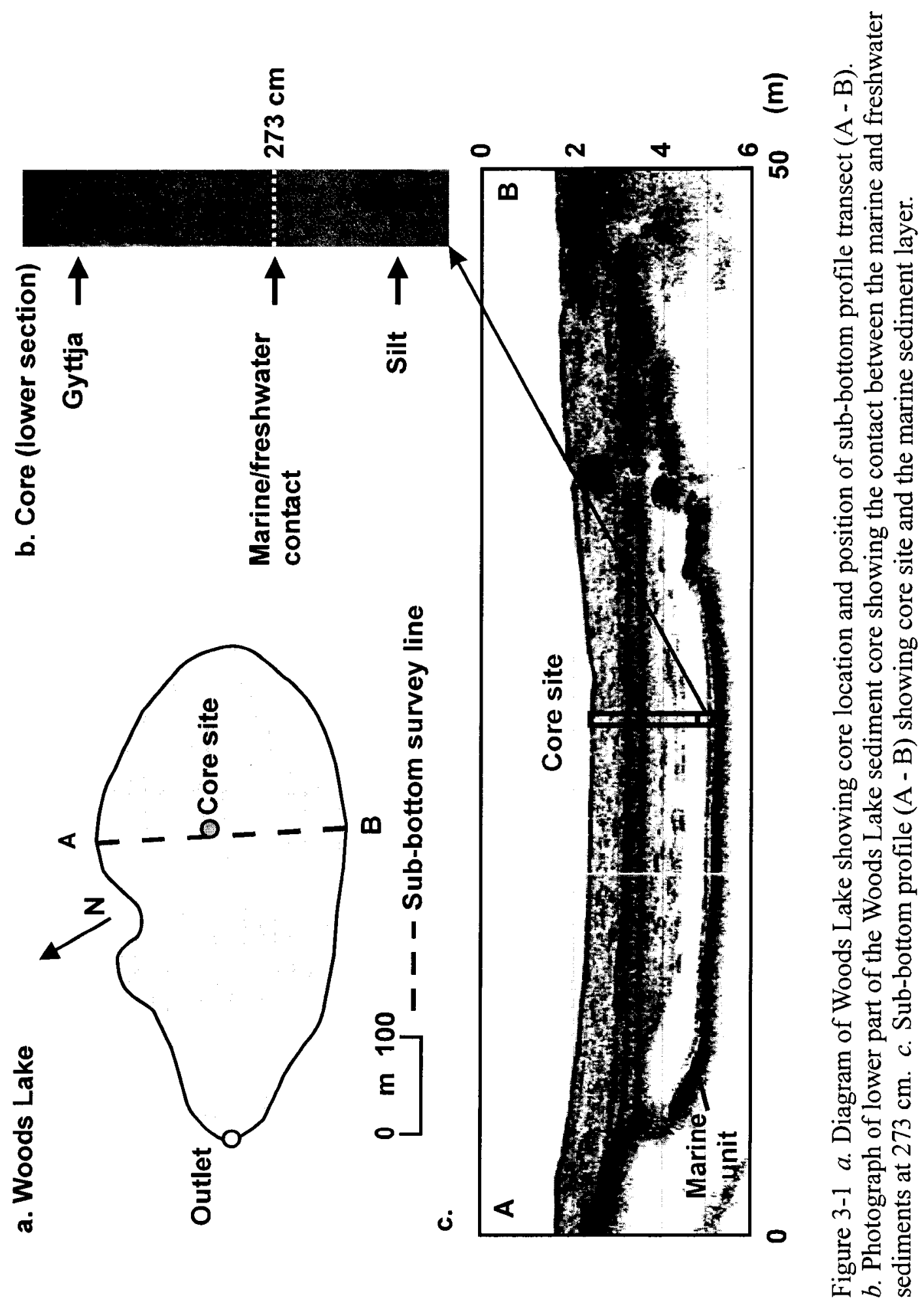




\subsection{Pollen preparation}

Fifty-two pollen samples of known volume were taken throughout the core $\left(0.5 \mathrm{~cm}^{3}\right.$, except for the two uppermost samples). One tablet of Lycopodium clavatum spores (Batch No. 938 934; $n=10,679$ spores/tablet) was added to each sample in order to calculate pollen concentrations (cf. Stockmarr, 1971). Pollen sample preparation followed standard techniques (cf. Faegri and Iversen, 1989) and involved treatment with potassium hydroxide, hydrochloric acid, sieving and hydrofluoric acid treatment and acetolysis. The samples were mounted in silicone oil. A bright field microscope was used to identify and count palynomorphs. Counting was carried out at $400 \mathrm{x}$ magnification. Pollen grains and fern spores attributable to terrestrial plant taxa were included in the main pollen sum, pollen of aquatics such as submerged and floating macrophytes were excluded. Since ferns represent a significant component of the upland vegetation in coastal forests of British Columbia, their spores were included in the main pollen sum (R. Mathewes, personal communication).

\subsection{Palynomorph identification and nomenclature}

Pollen and spore types were identified following Moore et al. (1991), with the exception of the following: Arceuthobium, Athyrium filix-femina and Ruppia for which identifications followed McAndrews (1973); Cupressaceae followed Kapp et al. (2000); Pinus diploxylon type, Pinus haploxylon type and Rosaceae followed Faegri and Iversen (1989); Tsuga heterophylla and Tsuga mertensiana followed Richard (1970). 
Identifications were also undertaken with reference to the modern pollen and spore reference collection of the Canadian Museum of Nature (Ottawa). Pollen and spore types that were not listed in the literature are described as follows.

The 'Pinus undiff.' pollen includes Pinus haploxylon type and Pinus diploxylon type, which could not be counted separately because distinguishable features (presence or absence of warts on the membrane between the bladders) were not always visible. The 'Ericaceae type' comprises grains that show morphological features of pollen grains that are produced by taxa of the Ericaceae family (cf. Moore et al., 1991). 'Lysichiton americanum' was identified by R. Mathewes (personal communication, 2003). 'Polypodiales: monolete incomplete' includes all monolete spores without perine. The 'Polypodium vulgare type' includes spores that were derived from one or more species of Polypodium (cf. Moore et al., 1991; cf. Mathewes and Rouse, 1975). 'Holodiscus discolor/Spirea' includes all pollen grains produced by the Rosaceae taxa Holodiscus discolor (Hebda et al., 1988) and/or Spirea (reference collection of the Canadian Museum of Nature, Ottawa).

Pediastrum species were identified and named following the key of Komárek and Jankovská (2001), stomata and trichomes followed MacDonald (2001) and Pals et al. (1980), Botryococcus followed Kapp et al. (2000). Microforaminifera were also tallied (cf. Mathewes, 1973; cf. Kapp et al., 2000). Identification of other palynomorphs followed Evitt (1969) (Hystrichospheres), Van Geel et al. (1989) (Spirogyra) and Van Geel (2001) (Filinia longiseta-type egg). The Filinia longiseta-type egg represents the 
resting stages of the planktonic rotifer taxa Filinia longiseta and Filinia passa (Van Geel, 2001).

\subsection{Calculation and data presentation}

Pollen concentration and percentage diagrams were constructed with the aid of the software packages TILIA 2.0.b.4 (Grimm, 1993) and TILIA-GRAPH 2.0.b.5 (Grimm, 1991). Concentration values (grains $/ \mathrm{mm}^{3}$ ) are displayed as histograms; percentage values as closed curves with an additional fivefold exaggeration (open curve), which was applied for low percentage values to aid in interpretation. Other palynomorphs (e.g., algal remains, stomata) are shown in a separate diagram and represented as percentage of the pollen sum or as present or absent (Figure 4-7). Radiocarbon dates and total pollen and spore concentrations are also shown. The 'Pollen sum' column displays the number of pollen grains included in the sum. The pollen and spore diagram was subdivided into local pollen zones by performing stratigraphically constrained cluster analysis of the square-root transformed percentage data using the computer program CONISS (Grimm, 1987). Only sum pollen and spore types with an occurrence of at least $2 \%$ of the pollen and spore sum were included in the calculation (cf. Pellatt et al., 2001). Aquatics were not included because the focus in this study is on upland vegetation (cf. Grimm, 1987). The resulting dendrogram is presented on the right site of the percentage pollen diagram. The palynologically defined zones are also shown in the 'other palynomorphs diagram' in 
order to determine whether significant changes in these palynomorphs occur simultaneously with changes in the pollen and spore spectra.

\subsection{Radiocarbon dates}

Radiocarbon dating of selected horizons was carried out to provide a chronological framework for the observed vegetation changes in the core. Three bulk sample of plant debris were submitted in July 2003 for AMS radiocarbon dating to the IsoTrace Laboratory, University of Toronto (Table 3-1). The first of the three samples was collected from the marine silt - limnic gyttja transition zone in the lower part of the core at 268-269 $\mathrm{cm}$ (Figure 3-1), and two additional samples were taken as 'range finders' at selected horizons (132-133 cm; 49.9-51.4 cm) in the limnic sediment above. Radiocarbon dating results were calculated by IsoTrace Laboratory using their $\mathrm{C} 14 \mathrm{Cal}$ program (Stuiver and Reimer, 1986, 1993; Stuiver et al., 1998a,b) along with the INTCAL98 dendrochronological database for terrestrial material and the MARINE98 reported database for marine material (Stuiver et al., 1998a,b). 


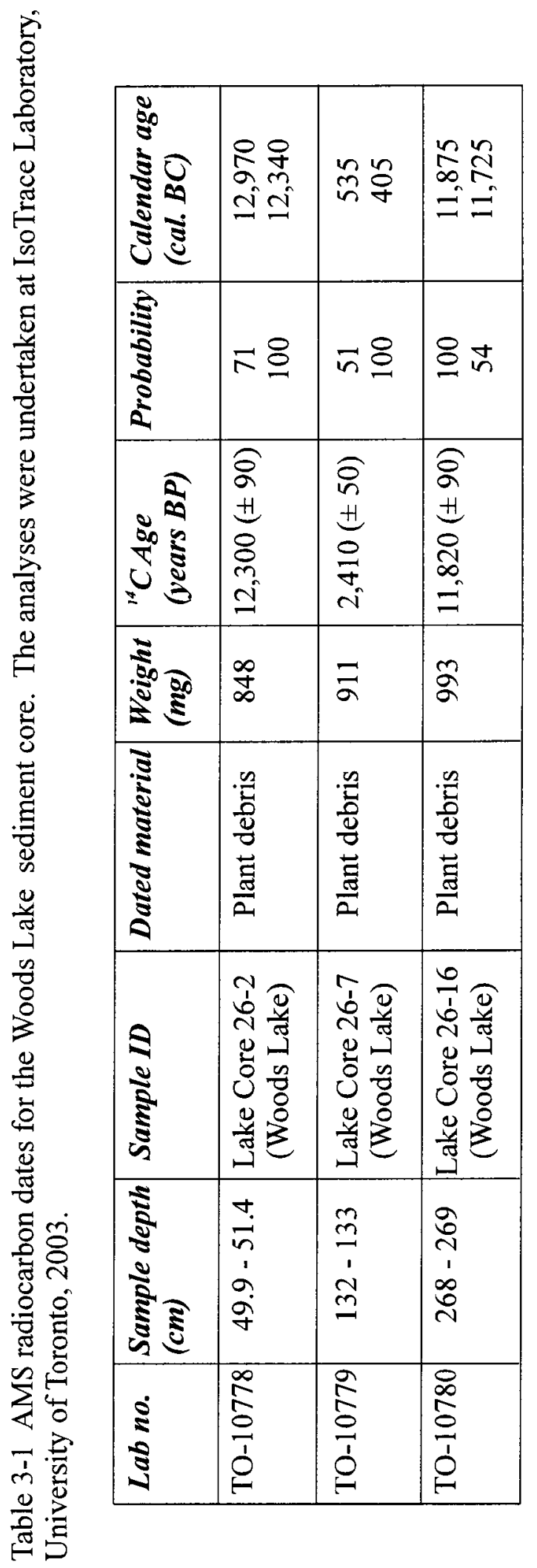




\section{$4 \quad$ Results}

\subsection{Pollen assemblage zones}

The percentage pollen and spore diagram (Figure 4-3) was subdivided into five pollen assemblage zones (WP-1 - WP-5) on the basis of the constrained cluster analysis (CONISS; Figure 4-1). When applicable, sub-zones were defined. Concentration values of pollen and spore types, sedimentology and radiocarbon dates corresponding to each zone are also described (Figures 4-2, 4-4 to 4-6). 


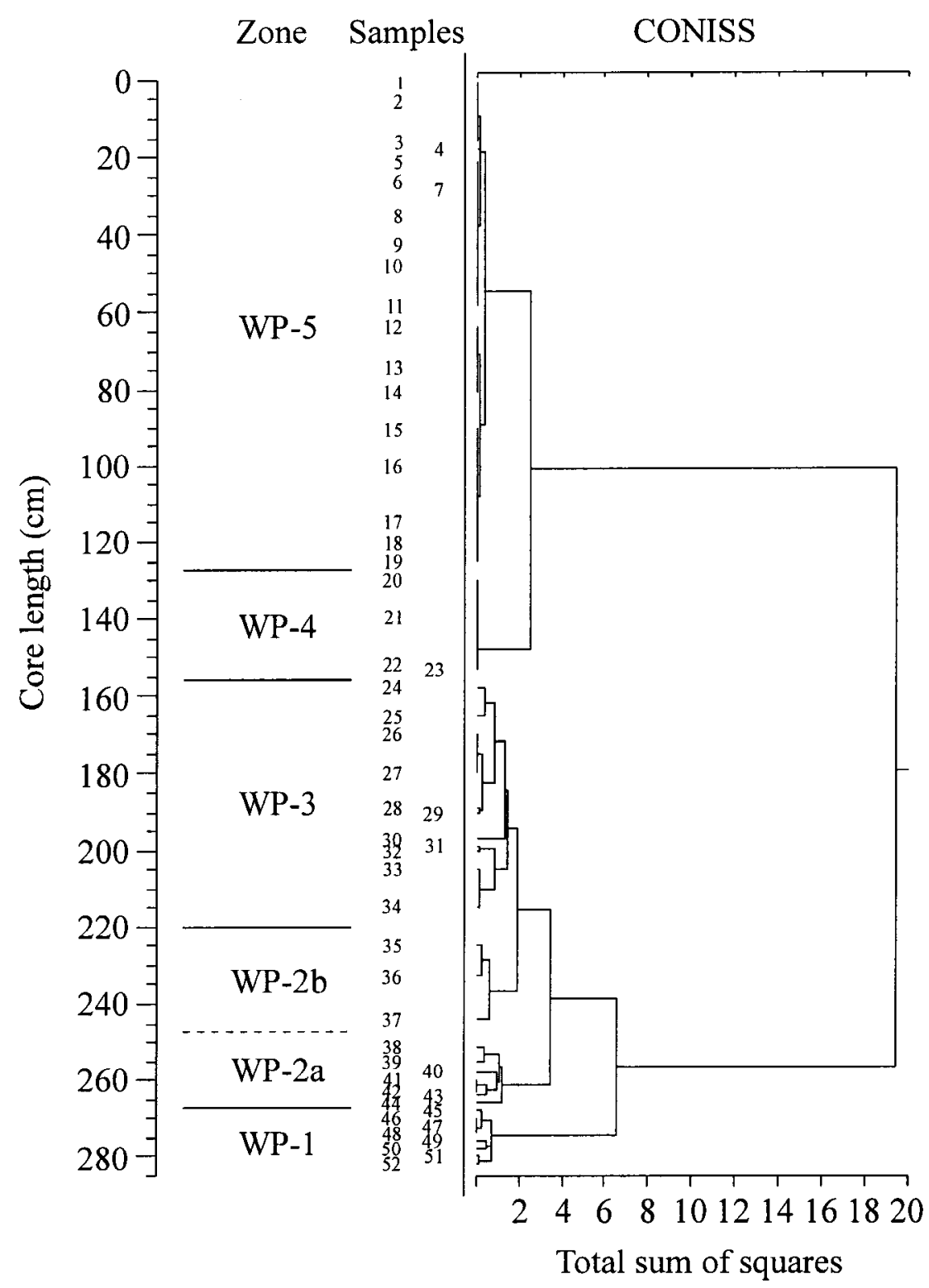

Figure 4-1 Dendrogram from constrained sum of squares cluster analysis (CONISS) of 52 samples from Woods Lake sediment core showing derived pollen assemblage zones and core length. 


\section{PAZ WP-1 (282-267 cm)}

The sediment that corresponds to zone WP-1 is composed of olive grey silt with scattered shell fragments and thin beds of coarse silt and fine sand in the lowermost $10 \mathrm{~cm}$. At $273 \mathrm{~cm}$ the silt is replaced by gyttja. A sample of gyttja from $268-269 \mathrm{~cm}$ yielded an age of $11,820 \pm 90{ }^{14} \mathrm{C}$ years $\mathrm{BP}$ (Table 3-1).

Pinus undiff. pollen is abundant throughout the zone with values up to $75 \%$; Pinus diploxylon type and Pinus haploxylon type pollen occur with undulating values (2\% to $12 \%$ and $8 \%$, respectively). Alnus and Tsuga mertensiana pollen show moderate values of $13 \%$ and $5 \%$, while Salix and Picea pollen occur with low values of $<1 \%$. Clumps of Alnus, Pinus undiff. and Populus pollen occur in the lowermost half of this zone, whereas Tsuga mertensiana pollen clumps occur in the uppermost part. Nonarboreal pollen (e.g., Cyperaceae, Artemisia) and spores (Polypodiales: monolete incomplete, Athyrium filix-femina, Polypodium vulgare type) are both present with values of $2 \%$ and $5 \%$, respectively. The centre of this zone $(276 \mathrm{~cm})$ is characterised by peak values of many arboreal pollen (e.g., Alnus, Populus, Tsuga mertensiana) accompanied by a decrease in Pinus undiff. pollen. In the lower part of the zone, Typha latifolia type pollen occurs at very low frequencies of $<1 \%$, while Ruppia pollen is present in the uppermost sample at frequencies of $1 \%$.

The total pollen and spore concentrations show high values of about 600 grains $/ \mathrm{mm}^{3}$ in the first half of this zone, which sharply decreases at $274 \mathrm{~cm}$ to 75 grains $/ \mathrm{mm}^{3}$ and subsequently recovers to 400 grains $/ \mathrm{mm}^{3}$ in the uppermost sample at $268 \mathrm{~cm}$. Similarly, the concentration of most arboreal pollen (e.g., Alnus, Tsuga 
mertensiana) and most spores (e.g., Athyrium filix-femina, Polypodium vulgare type)

shows increasing values towards the centre of zone WP-1 followed by a sharp decrease at $274 \mathrm{~cm}$. The concentrations of Pinus diploxylon type, Pinus haploxylon type and Pinus undiff. pollen, however, recover and reach high values in the uppermost sample $(268 \mathrm{~cm})$.

\section{PAZ WP-2 (267-220 cm)}

The sediment that corresponds to zone WP-2 comprises greyish brown and dark olive grey gyttja, which extends from $267 \mathrm{~cm}$ to $259 \mathrm{~cm}$. At $259 \mathrm{~cm}$ the gyttja becomes darker and includes occasional small plant and wood fragments. The very dark brown organic gyttja extends to the top of the zone $(220 \mathrm{~cm})$.

This zone is distinguished from the preceding zone by lower proportions of Pinus diploxylon type (6\%), Pinus haploxylon type (1\%), and Pinus undiff. pollen (23\%), accompanied by higher values of Tsuga mertensiana (17\%), non-arboreal pollen (e.g., Cyperaceae, Artemisia, Ericaceae type, Rosaceae pollen) and spores (e.g., Athyrium filixfemina, Polypodium vulgare type, Pteridium aquilinum). Salix pollen remains at low frequencies of $<1 \%$. Clumps of Tsuga mertensiana and Alnus pollen are occasionally present throughout this zone. Amongst the aquatics, Nuphar pollen is first recorded at $258 \mathrm{~cm}$ and present at low continuous frequencies $(<1 \%)$. The total pollen and spore concentrations remain at values of about 400 grains $/ \mathrm{mm}^{3}$.

This zone is subdivided into two subzones, WP-2a and $2 b$. The beginning of subzone WP-2a $(267-247.5 \mathrm{~cm})$ is marked by a sharp increase in Alnus pollen values. 
Picea (22\%), Abies ( $8 \%$ ) and Populus pollen (5\%) occur at higher values relative to zone WP-1. The middle of this subzone $(258 \mathrm{~cm})$ is characterised by a peak in Alnus pollen of $70 \%$ accompanied by a decline in the percentages of the other arboreal pollen (e.g., Tsuga mertensiana, Picea, Abies pollen). The concentrations of the aforementioned arboreal pollen types have higher values than in the preceding zone. High concentration values of Alnus pollen in the middle of the zone $(258 \mathrm{~cm})$ are accompanied by decreased values of the other arboreal pollen types.

Subzone WP-2b $(247.5-220 \mathrm{~cm})$ is characterised by a significant increase in Tsuga heterophylla pollen, which attains peak frequencies of $34 \%$ in the uppermost sample $(225 \mathrm{~cm})$. Clumps of Tsuga heterophylla pollen occur. Alnus (13\%), Picea (5\%) and Abies pollen (<1\%) are less abundant than in subzone WP-2a, while Populus pollen disappears in this subzone. Non-arboreal pollen (mainly Lysichiton americanum pollen) and aquatics (mainly Potamogeton subg. potamogeton pollen) are abundant in the two uppermost samples. The concentration of Tsuga heterophylla pollen attains high values (110 grains $\left./ \mathrm{mm}^{3}\right)$, whereas the other arboreal pollen are present at lower values relative to subzone WP-2a.

\section{PAZ WP-3 (220-155.5 cm)}

The sediment that corresponds to zone WP-3 is very dark brown organic gyttja with occasional small plant and wood fragments.

This zone is defined by another sharp increase in the abundance of Alnus pollen (73\%), whose pollen clumps are present throughout the zone. Picea pollen (up to $15 \%$ ), 
non-arboreal pollen (e.g., Rosaceae [2 \%], Holodiscus discolor/Spirea [1 \%], Lysichiton americanum pollen [ca. $5 \%$ ]) and spores (e.g., Pteridium aquilinum, Polypodium vulgare type) attain higher values than in the previous zone, while Pinus undiff. (10\%), Tsuga mertensiana (1\%) and Tsuga heterophylla (ca. 10\%) pollen are generally present at lower values. Larix type pollen occurs at frequencies of ca. $7 \%$ in two samples in the middle part of the zone $(200$ and $199 \mathrm{~cm})$. At $197 \mathrm{~cm}$, Tsuga heterophylla, Pinus undiff. and Tsuga mertensiana pollen show frequency peaks of $24 \%, 20 \%$ and $12 \%$, whilst Alnus and Picea pollen show a decline in frequency (24\% and $3 \%$, respectively). The high values of Tsuga heterophylla pollen are accompanied by clumps of this pollen type. Pollen of Cupressaceae shows a minor peak (10\%) at the top of the zone. Pollen of Potamogeton subg. potamogeton peaks (9\%) in the middle of this zone at $197 \mathrm{~cm}$; Nuphar pollen is present at higher abundances than in the previous zone. The total pollen concentration values are higher than in the previous zone, but undergo a decline between $200 \mathrm{~cm}$ and $197 \mathrm{~cm}$ and at the top of the zone $(165-158 \mathrm{~cm})$. Alnus, Picea, Lysichiton americanum pollen and Pteridium aquilinum spore all occur generally at higher concentrations than in subzone WP-2b. Larix type pollen reaches values of 17 grains $/ \mathrm{mm}^{3}$ in the centre of the zone at $200-199 \mathrm{~cm}$, coinciding with low concentrations of Tsuga heterophylla and Tsuga mertensiana pollen, which attain higher concentrations in the following sample $(197 \mathrm{~cm})$. At $197 \mathrm{~cm}$, Alnus and Picea pollen attain low concentrations and recover in the following sample. 
PAZ WP-4 (155.5-127.5 cm)

Very dark brown gyttja corresponds to zone WP-4. This is replaced at $132.5 \mathrm{~cm}$ by a lighter coloured olive gyttja with coarse sand, small pebbles $(0.5-1 \mathrm{~cm})$ and occasional wood fragments, (>ca. $1 \mathrm{~cm}$ diameter). A gyttja sample from the top of the zone $(133-132 \mathrm{~cm})$ is dated at $2,410 \pm 50{ }^{14} \mathrm{C}$ years $\mathrm{BP}$.

Zone WP-4 is distinguished from the previous zone by a sharp increase in the frequency of Cupressaceae pollen (ca. $40 \%$ ). Clumps of Cupressaceae pollen are continuously present. Alnus and Picea pollen, non-arboreal pollen (e.g., Rosaceae, Lysichiton americanum, Holodiscus discolor/Spirea pollen) and spores (Polypodium vulgare type, Pteridium aquilinum spore) are present at lower frequencies. Larix type pollen is continuously present at low frequencies $(<1 \%)$. The total pollen and spore concentrations remain at low values and are similar to those at the top of the previous zone. Concentration values of Cupressaceae pollen are higher than in zone WP-3.

\section{PAZ WP-5 (127.5-0 cm)}

The sediment that corresponds to the lowermost part of zone WP-5 comprises very dark greyish brown gyttja with large detrital wood fragments $(2 \mathrm{~cm}+)$ and occasional stones $(0.5-1 \mathrm{~cm})$. This is replaced at $119 \mathrm{~cm}$ by an olive-colored gyttja with occasional small pebbles $(2-3 \mathrm{~mm})$ and plant fragments, which extends to $28.5 \mathrm{~cm}$. The uppermost part $(28.5-0 \mathrm{~cm})$ is composed of black and very dark grey-brown gyttja. A gyttja sample from $49.9-51.4 \mathrm{~cm}$ yielded an age of $12,300 \pm 90{ }^{14} \mathrm{C}$ years BP. 
Zone WL-E is characterised by another increase in the frequency of Cupressaceae pollen $(80 \%)$ and lower abundances of Alnus, Picea, Pinus undiff. pollen, non-arboreal pollen (e.g., Rosaceae, Lysichiton americanum, Holodiscus discolor/Spirea pollen) and spores (e.g., Pteridium aquilinum, Polypodium vulgare type spore). Clumps of Cupressaceae pollen are present throughout the zone. Pollen of Larix type occurs occasionally. Ruppia pollen is present at values of ca. $2 \%$ at $58.55-63.87 \mathrm{~cm}$ in the middle of the zone. The total pollen concentration remains stable throughout the zone and shows a fivefold increase at $5.32 \mathrm{~cm}$. The concentration values of Alnus and Picea pollen are lower than in the previous zone, while Cupressaceae pollen occurs at higher concentrations. Pollen of many arboreal taxa (e.g., Cupressaceae, Tsuga heterophylla pollen) and some spores (e.g., Polypodium vulgare type, Pteridium aquilinum spore) reach high concentrations at the top of the zone. Ruppia pollen occurs in the middle of the zone $(58.55-63.87 \mathrm{~cm})$ at concentrations of ca. $5 \%$. 


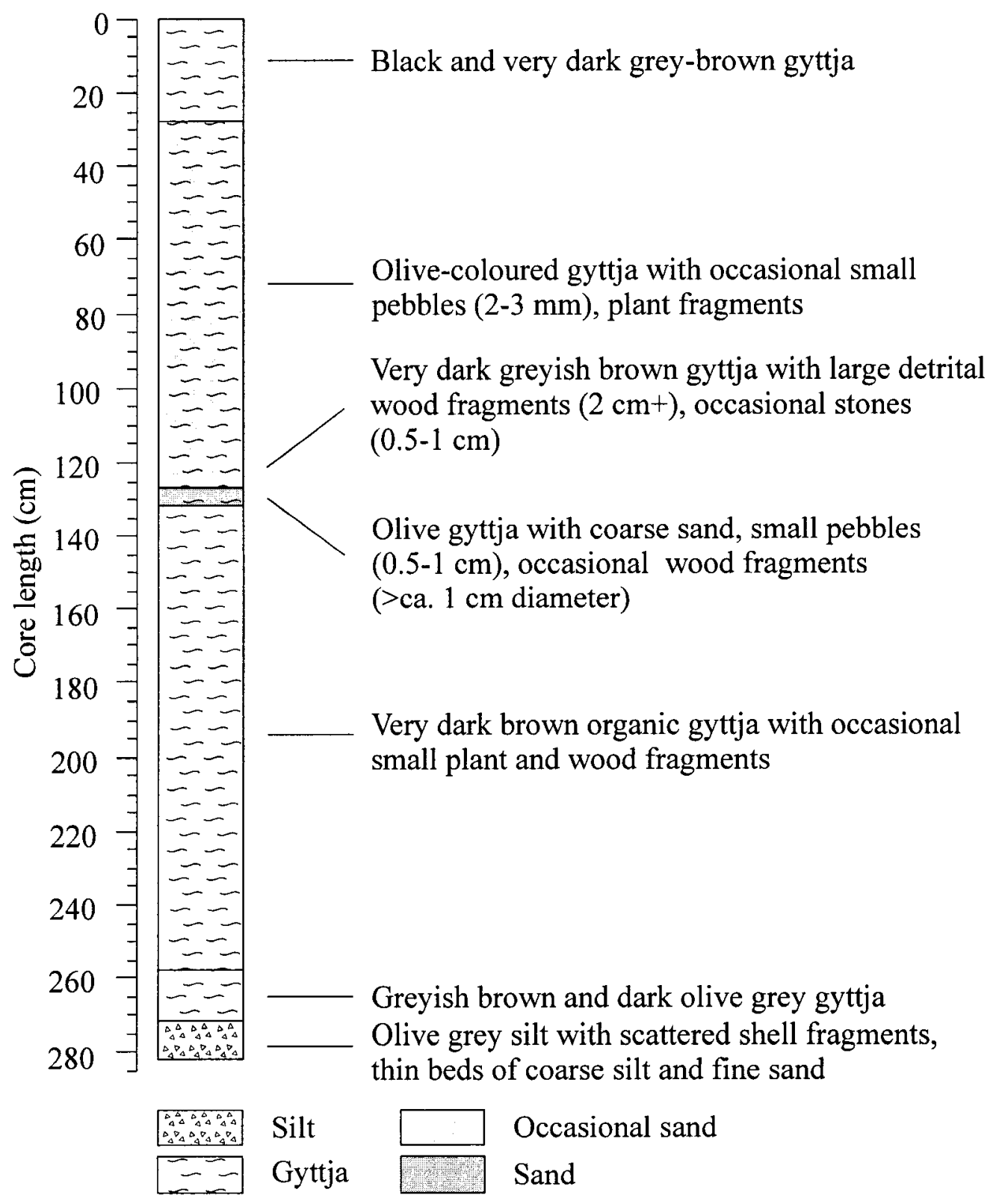

Figure 4-2 Detailed sedimentological overview of the Woods Lake core. 


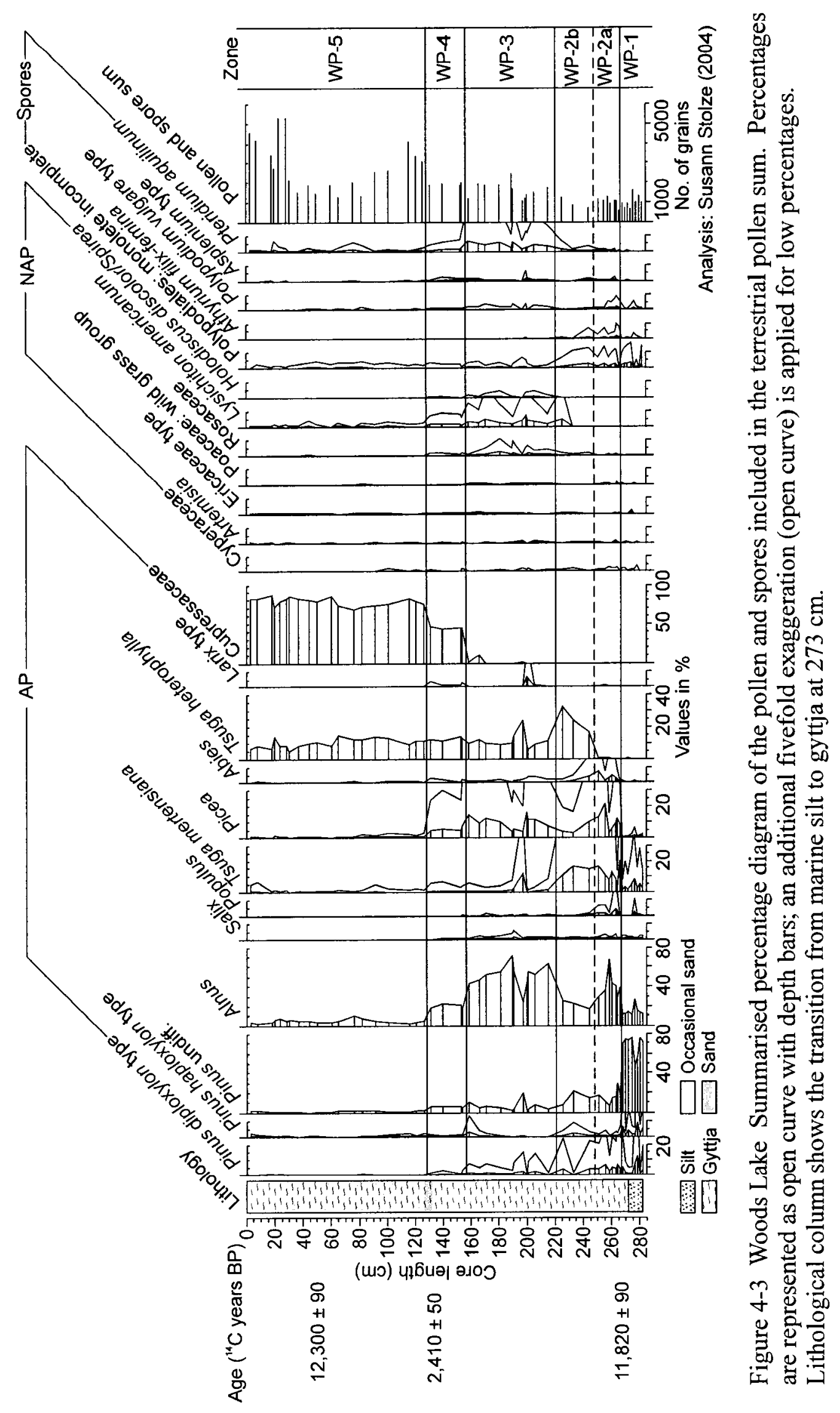




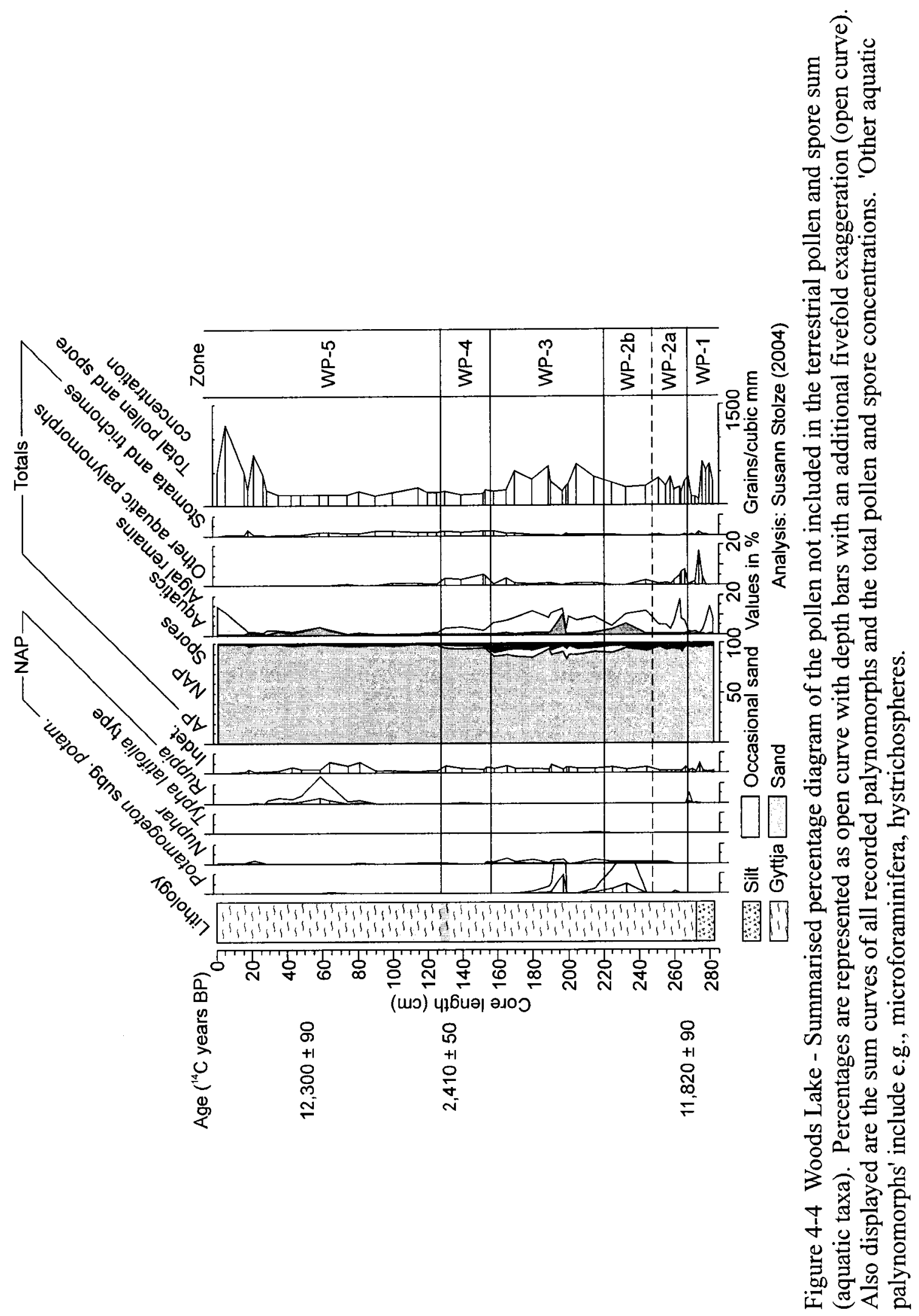




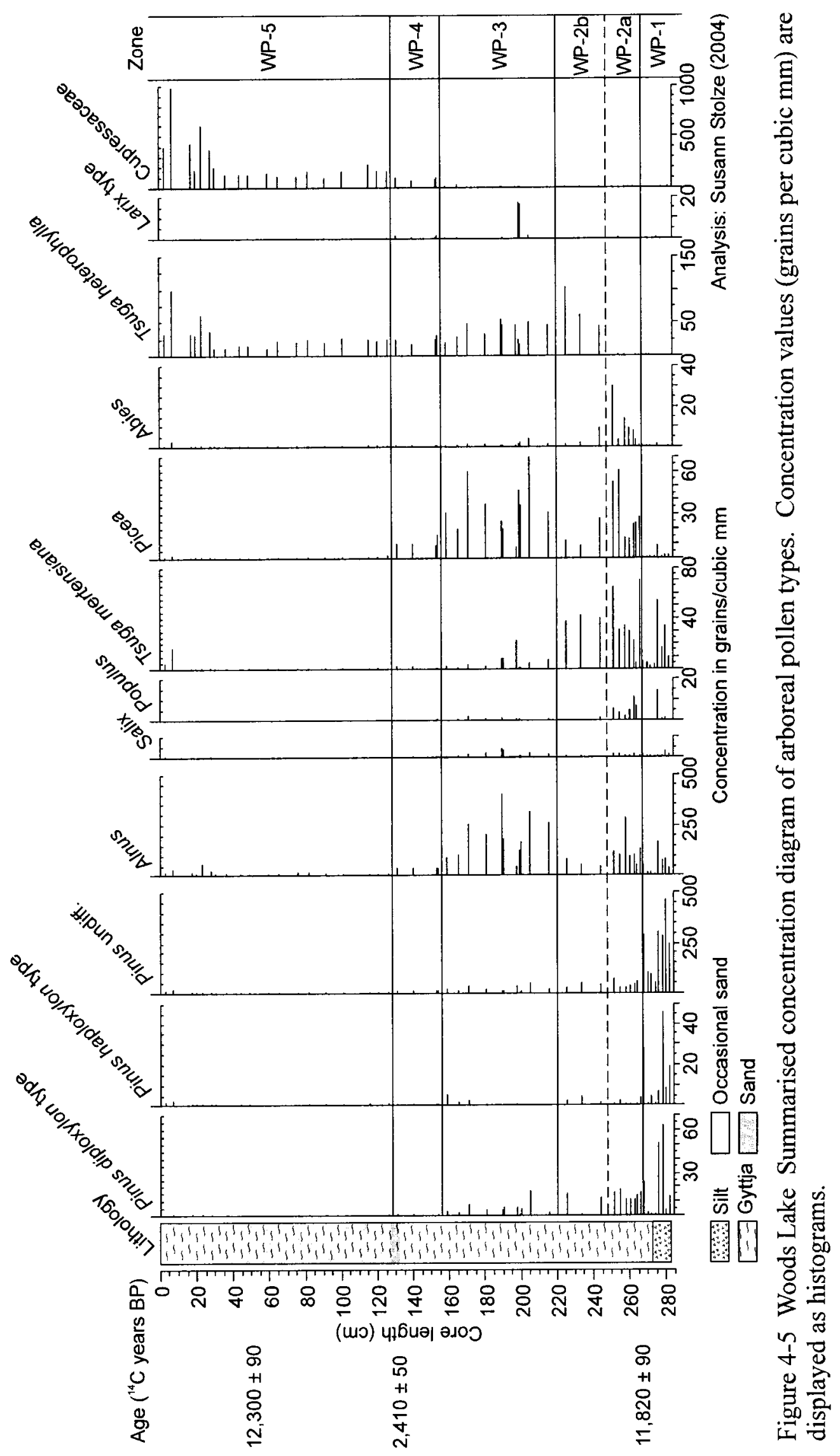




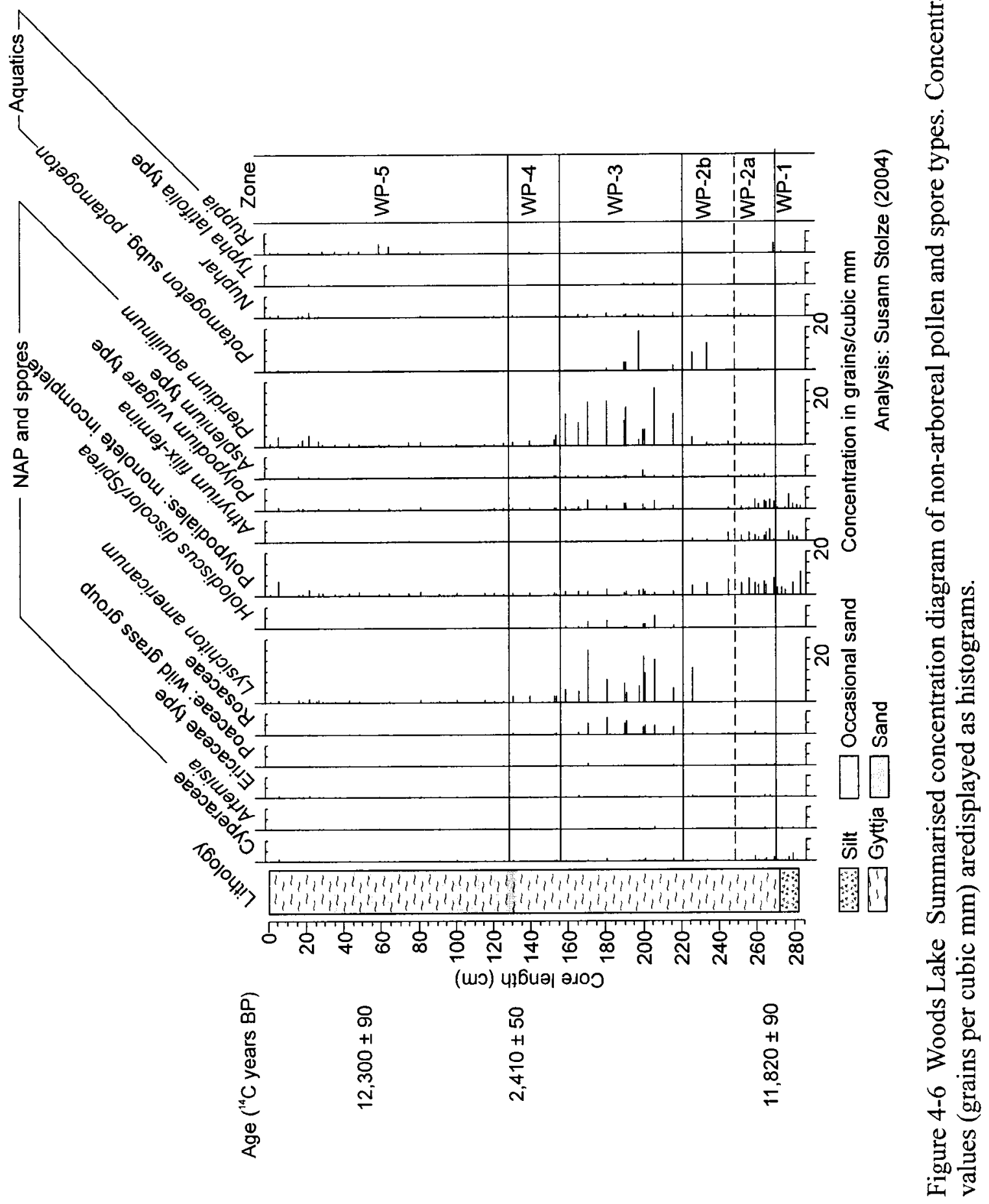




\subsection{Other palynomorphs}

The main characteristics of the other palynomorphs (Figure 4-7) are described for each PAZ, which were defined for the main pollen percentage diagram (Figure 4-3).

\section{PAZ WP-1 (282-267 cm)}

Algal remains are present at high frequencies (especially Pediastrum boryanum at $11 \%)$ in the lower half of this zone, and decline sharply in the upper half where microforaminifera and hystrichospheres make their first appearance. Nymphaeaceae hairs and Pinus stomata are continuously present throughout the zone, and Picea stomata appear in the uppermost sample.

\section{PAZ WP-2 (267-220 cm)}

Algal remains are abundant throughout this zone. Botryococcus attains high percentage values, up to $18 \%$, in subzone WP-2a, whereas Spirogyra zygospores reach values of $6 \%$ in subzone WP-2b. Nymphaeaceae hairs are present throughout the zone. Pinus stomata disappear completely, whilst stomata of Picea occur occasionally. Filinia longiseta-type egg is first recorded in this zone at $266 \mathrm{~cm}$ and occurs occasionally.

\section{PAZ WP-3 (220-155.5 cm)}

Algal remains, mainly Botryococcus, show higher values than in the previous zone but decline in the middle of the zone. Picea stomata and Nymphaeaceae hairs are 
continuously present. Chamaecyparis/Thuja stomata occur twice at $215 \mathrm{~cm}$ and $165 \mathrm{~cm}$. Hystrichospheres appear at the end of zone WP-3 and peak at $165 \mathrm{~cm}$.

\section{PAZ WP-4 (155.5-127.5 cm)}

Algal remains occur at lower values than in zone WP-3. Picea stomata, Chamaecyparis/Thuja stomata and Nymphaeaceae hairs are present. Stomata of Thuja and Tsuga heterophylla were recognised in the lowermost sample $(153 \mathrm{~cm})$, stomata of Abies in the uppermost sample $(130 \mathrm{~cm})$. Hystrichospheres occur continuously throughout the zone at values of up to $5 \%$.

\section{PAZ WP-5 (127.5-0 cm)}

Botryococcus is represented in lower abundances $(<1 \%)$ than in zone WP-4 but shows a steep increase in abundance (up to $15 \%$ ) at the top of zone WP-5 $(5.32-1 \mathrm{~cm}$ ). Stomata of several taxa (e.g., Picea, Thuja) are present throughout the zone. Nymphaeaceae hairs are not present throughout most of the zone but re-appear at $26.61 \mathrm{~cm}$. Other microfossils apart from hystrichospheres disappear completely. 


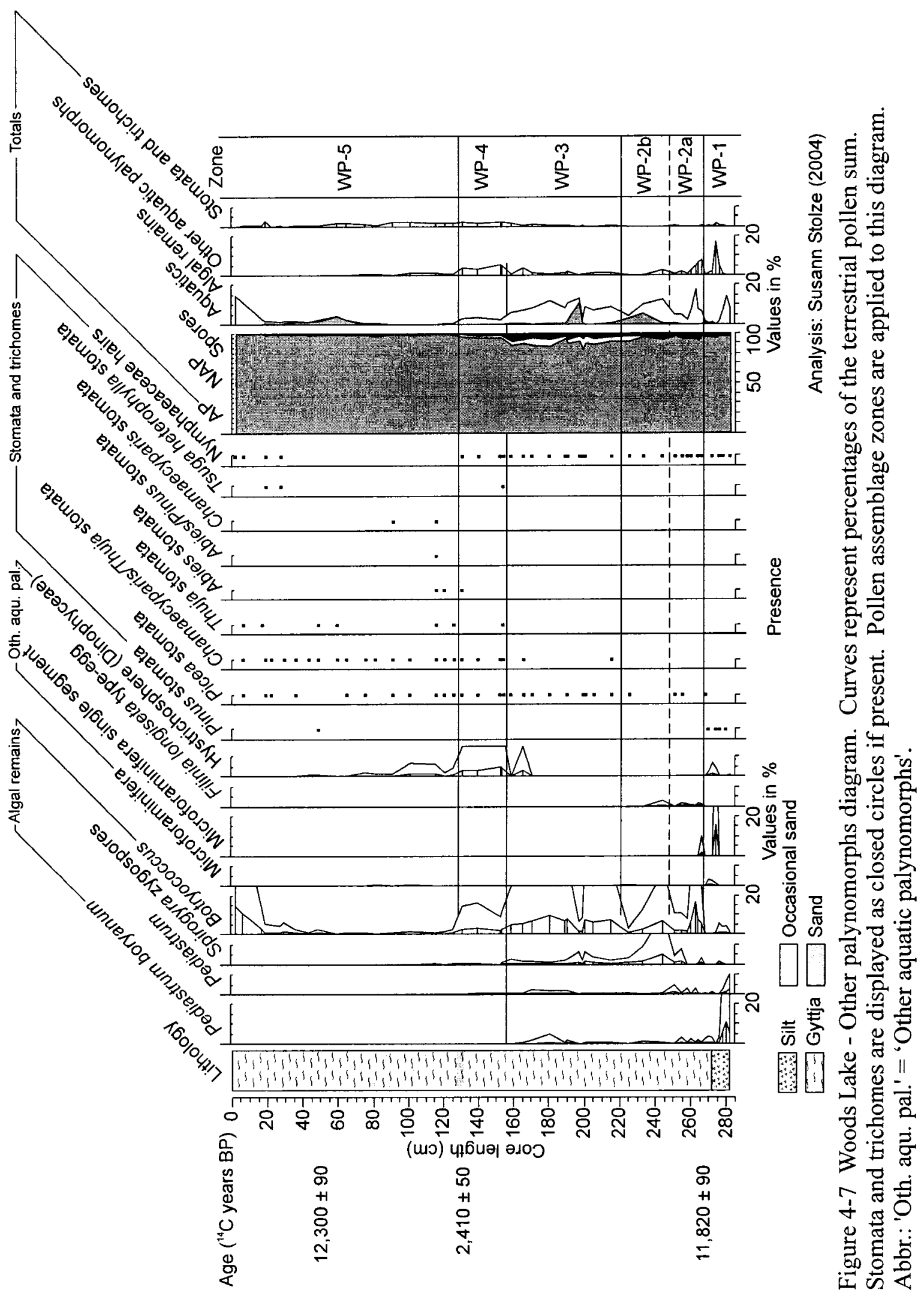




\section{Discussion}

\subsection{Vegetation and environmental history}

\section{Pinus - Alnus - Tsuga mertensiana phase (PAZ WP-1, 282-267 cm)}

The pollen record indicates that during the early phase of silt accumulation the vegetation around Woods Lake was dominated by pine (Pinus), alder (Alnus) and mountain hemlock (Tsuga mertensiana). Willow (Salix), spruce (Picea) and fir (Abies) also occurred. The fact that Pinus undiff. pollen attains $75 \%$ of the terrestrial pollen and spore sum might imply that pine was growing near the lake (cf. Hebda and Allen, 1993). However, it must be taken into account that Pinus pollen is notoriously overrepresented (e.g., Hebda and Allen, 1993; Faegri and Iversen, 1989). In recently deglaciated or sparsely vegetated landscapes, where the overall pollen production is low, Pinus pollen dominates the percentage picture, however, not indicating a pine forest (Faegri and Iversen, 1989). Another type of overrepresentation occurs due to the buoyancy properties of the vesiculate and relatively light Pinus pollen grains, which float on the water surface and often accumulate in littoral sediments (Faegri and Iversen, 1989). Thus, the high values of Pinus undiff. pollen recorded in PAZ WP-1 in the Woods Lake diagram might also be a result of marine inundation and deposition of marine silts. A possible occurrence of pine in close vicinity to the lake may be indicated by the presence of Pinus stomata in the sediment (e.g., cf. Lacourse et al., 2003) and by the occurrence of Pinus undiff. pollen clumps (cf. Faegri and Iversen, 1989). At present, Pinus contorta (lodgepole pine), $P$. ponderosa (yellow pine), $P$. monticola (western white pine), $P$. 
flexilis (limber pine) and P. albicaulis (whitebark pine) grow in the Pacific Northwest region (Ritchie, 1987; Pojar and MacKinnon, 1994). The first two species produce pollen grains of the Pinus diploxylon type, whereas the last three species release pollen of the Pinus haploxylon type (Ritchie, 1987). For Cook Bank (north of Vancouver Island) and Juan Perez Sound (Queen Charlotte Islands), Lacourse et al. (2003) have shown by macrofossil analysis that Pinus contorta was an important component on the northwest Pacific coast during the late glacial. Other than Pinus monticola, P. flexilis and $P$. albicaulis have not been recorded in fossil material in this region (cf. Ritchie, 1987). This suggests that probably lodgepole pine and western white pine played a role around Woods Lake. Heusser (1983) proposed that communities of Pinus contorta, Pinus monticola and Alnus were common for the late glacial in the pollen record from Saanich Inlet, Vancouver Island. A pine-dominated vegetation was suggested as a result of soil immaturity and disturbed substrates (Hebda, 1983).

Relatively high values of Tsuga mertensiana pollen, up to $7 \%$ of the terrestrial pollen and spores sum, suggest that mountain hemlock grew in close vicinity to the lake (cf. Mathewes, 1993). This is confirmed by the presence of Tsuga mertensiana pollen clumps (cf. Faegri and Iversen, 1989).

The relatively low values of Picea and Abies pollen $(<2 \%)$ suggest a regional occurrence of spruce and fir (cf. Hebda and Allen, 1993). However, alongside with the low values of Picea pollen in the uppermost sample of PAZ WP-1, Picea stomata were 
also found, reflecting its extralocal ${ }^{1}$ occurrence. The relative abundance of fern spores in the pollen record might suggest that ferns represented a significant part of the vegetation. Lacourse et al. (2003) stated that ferns formed an important portion of the understorey of the late-glacial landscape near northern Vancouver Island. However, in marine sediments fern spores can be overrepresented due to their resistance to breakdown (Havinga, 1984). Thus, the increased frequency of fern spores might also result from the marine inundation and input of marine sediments. In summary, a pine dominated vegetation - most probably Pinus contorta - with mountain hemlock and spruce presumably defined this phase, suggesting a cool and moist climate (cf. Ritchie, 1987, cf. Hebda and Allen, 1993). Pollen assemblages dominated by pine are typical for lateglacial assemblages on the northwest Pacific coast (cf. Hebda, 1983).

The middle of this phase is marked by an expansion of alder (Alnus) and poplar (Populus). Clumps of Alnus pollen may indicate the extralocal presence of this taxon (cf. Faegri and Iversen, 1989). As Populus pollen is often poorly preserved (cf. Janssen, 1966, 1984; cf. Faegri and Iversen, 1989), low values of $2 \%$ may indicate that poplar was relatively abundant in the landscape (cf. Faegri and Iversen, 1989). The increased presence of these shade-intolerant taxa may reflect the occurrence of disturbed forest areas around the lake (cf. Ritchie, 1987; cf. Klinka et al., 1989). It may also reflect wetter edaphic conditions (cf. Klinka et al., 1989), as during this period a higher sea level (see below) is likely to have led to increased water tables and thus wetter edaphic conditions.

\footnotetext{
${ }^{1}$ The terms 'local', 'extralocal' and 'regional' are used in this paper as defined in Janssen $(1966,1967)$.
} 
The presence of Nuphar and Typha latifolia type pollen and an increased occurrence of algal remains (e.g., Pediastrum boryanum) through the first half of this phase indicate freshwater conditions (cf. Klinka et al., 1989; cf. Komárek and Jankovská, 2001). In contrast, diatom analytical results indicate that marine conditions prevailed in the Woods Lake basin for the first half of this phase (C. Doherty, personal communication, 2004). This interpretation is supported by the sediments, which comprise olive grey silt with scattered shell fragments and thin beds of coarse silts and fine sand (cf. Clague, 1989). Deposition of marine sediments and occurrence of marine diatom taxa (e.g., Paralia sulcata) indicate a high relative sea level in the Seymour Inlet complex during this period. The high pollen and spore concentrations observed in this phase may reflect an increase in the size of the pollen source area as pollen was introduced into the basin from marine sources. The presence of coarse sediment adds support to this and suggests the introduction of allochthonous material in the lake basin and a probable consequent input and accumulation of re-deposited pollen and spores. The high pollen and spore concentrations may also reflect a low sedimentation rate or the presence of well-preserved pollen and spores or both of them. The second half of zone WP-1 is characterised by the occurrence of hystrichospheres, which represent cysts of Dinoflagellates (Dinophyceae), microforaminifera and Ruppia pollen, suggesting saline water conditions (cf. Kuhry, 1985; Mathewes, 1973). Ruppia pollen is produced by Ruppia spiralis and Ruppia occidentalis, both of which occur along the northwest Pacific coastline, inhabiting quiet, shallow brackish or saline water (Pojar and MacKinnon, 1994). In contrast, during this second interval the silts were replaced by gyttja, possibly 
suggesting freshwater conditions in the basin. The diatom record indicates that brackish conditions followed by freshwater conditions prevailed in the lake during this interval (C. Doherty, personal communication, 2004), suggesting a fall in relative sea level and the isolation of the basin from the sea. The lithological change is accompanied by decreased pollen and spore concentrations, which might reflect a change in the pollen source area as the input of re-deposited pollen and spores from marine sources ceased.

Noteworthy for pollen assemblage zone WP-1 is the occurrence of clumps of different pollen types as seen above. On one hand, this might reflect the close presence of plant taxa to the sampling site (cf. Faegri and Iversen, 1989), on the other hand, however, the grain clumping could be also a result of the preparation process through e.g., insufficient stirring of the pollen samples before the counting. 


\section{Alnus - Tsuga mertensiana - Pinus phase (PAZ WP-2, 267-220 cm)}

This vegetation phase is marked by a significant decrease in pine and an expansion of alder and other coniferous trees such as mountain hemlock and spruce. This phase is divided into two intervals, which are discussed below. An abrupt increase in Alnus pollen similar to the increase found in the Woods Lake pollen record has been noted in other pollen records from mainland southwestern British Columbia and Vancouver Island (Mathewes, 1973; Heusser, 1983). The expansion of alder might indicate climatic warming (cf. Heusser, 1960) or increased moisture (cf. Klinka et al., 1989) due to e.g., elevated water tables. Pine might still have played a role in the regional vegetation, even though percentage and concentration values of Pinus undiff. pollen decreased drastically in PAZ WP-2. This pine decline may indicate that shadetolerant conifers (e.g., Abies), which grow on humus-enriched soils, replaced the shadeintolerant pine in the landscape (cf. Banner et al., 1983). In addition, a change in the pollen source area may explain the decreased pine pollen values. In the preceding vegetation phase, marine inundation might have led to an increased accumulation of Pinus undiff., Pinus diploxylon type and Pinus haploxylon type pollen (cf. Faegri and Iversen, 1989), whereas the change from marine to lacustrine conditions might have resulted in a decreased input. The emergence of low-lying coastal land in the vicinity of Woods Lake might have promoted the expansion of spruce (Picea). At present, Picea sitchensis is common on the northwest Pacific coast where it forms stands on sites affected by ocean spray and brackish water (Klinka et al., 1989). The high values of Tsuga mertensiana pollen (17\%) indicate a significant expansion of mountain hemlock 
in the vicinity of the lake as a dominant or co-dominant part of the forest (cf. Hebda, 1983; Mathewes, 1993). This hypothesis is further confirmed by the presence of Tsuga mertensiana pollen clumps (cf. Faegri and Iversen, 1989). Subalpine mountain hemlock is an indicator of a cool and humid climate and snowy winters (cf. Heusser, 1978; Mathewes, 1993). Similar peaks in Tsuga mertensiana pollen dated between 11,000 and $10,000{ }^{14} \mathrm{C}$ years BP have been reported on the Pacific coast and attributed to Younger Dryas cooling (Hebda, 1983; Luternauer et al., 1989; Lacourse et al., 2003). The increased conifer diversity and abundance indicates a cool and moist climate, which characterised the latter part of the late-glacial interval (cf. Brown et al., 2003). Brown and Hebda (2003) showed that mixed coniferous forest was widespread during the late late glacial $(13,460-11,400 \mathrm{cal} \mathrm{BP})$ on the Pacific coast. The marked increase in alder may suggest that this phase was warmer than the preceding pine phase but cooler than present-day climate in the region (cf. Heusser, 1960). The abundance of fern spores such as Athyrium filix-femina and Polypodium vulgare type spores in PAZ WP-2 suggests that ferns (e.g., Athyrium filix-femina) may have represented a significant portion of the understorey of the coniferous forest (cf. Lacourse et al. 2003). The presence of nonarboreal pollen (e.g., Artemisia, Cyperaceae pollen) indicates that scattered openings existed in the landscape (cf. Brown and Hebda, 2003).

As mentioned above, this vegetation phase is divided into two intervals. The first interval is characterised by a high abundance of alder around Woods Lake. Alder might have expanded on damp sites immediately adjacent to the lake, which is suggested by the presence of Alnus pollen clumps, or in the coastal forest (cf. Ritchie, 1987). Alternatively 
it may have developed on for example, fire-disturbed areas with unstable edaphic conditions (cf. Lacourse et al., 2003). Another factor, which may have promoted an expansion of alder, might have been a climatic warming as suggested previously. Populus shows another significant expansion. Like alder, it may have expanded probably on moist sites or disturbed upland areas around Woods Lake (cf. Pojar and MacKinnon, 1994). The relatively high values of Abies and Picea pollen (up to $8 \%$ and $22 \%$ respectively) suggest the expansion of fir and spruce in the forest around Woods Lake during this phase. As Abies pollen is generally under-represented in lake pollen records (Reille, 1990), these pollen values indicate that Abies became an important element of the forest (cf. Janssen, 1966; cf. Hebda, 1983). The presence of Picea stomata indicates the existence of spruce immediately adjacent to the lake (cf. MacDonald, 2001). The occurrence of Larix type pollen probably reflects the presence of Pseudotsuga menziesii in the forest vegetation in the latter half of this interval. Larix type pollen (after Moore $e t$ al., 1991) includes Larix and Pseudotsuga pollen, since both types are indistinguishable from each other. As Pseudotsuga menziesii (Douglas-fir) is the likely tree species in the study area, the Larix type pollen will be ascribed to Douglas-fir.

The second interval is marked by a sudden expansion and abundance of western hemlock in the landscape, as indicated by a sharp increase in the frequency of Tsuga heterophylla pollen (up to $32 \%$ ) (cf. Hebda and Allen, 1996), indicating wetter conditions. A similar sudden appearance and sharp rise in Tsuga heterophylla pollen was also found in the pollen record at Bear Cove, northern Vancouver Island (Hebda, 1983). Alder, spruce and fir declined significantly in the forest around Woods Lake. However, 
spruce still grew near the lake, as suggested by the presence of Picea stomata. A mixed forest of western hemlock, mountain hemlock, pine and spruce can be assumed. The end of this interval is characterised by an increase in herbaceous plants, suggesting an opening of the landscape due to disturbance or increased temperatures or both. Skunk cabbage (Lysichiton americanum) showed a conspicuous expansion, probably growing on the lake fringe or on wet sites in the forest around the lake (cf. Pojar and MacKinnon, 1994). This species is characteristic for nutrient rich wetlands (Klinka et al., 1989).

The presence of Botryococcus colonies and Spirogyra zygospores throughout this interval indicates freshwater conditions (cf. Lacourse et al. 2003; cf. Van Geel et al., 1989). The change from marine to freshwater conditions in the lake indicates the isolation of the basin from the sea. A decline in algal remains, mainly Botryococcus, occurred in the middle of the first interval of this vegetation phase, coinciding with a lithological change from greyish brown and dark olive grey gyttja to black organic gyttja with occasional small plant and wood fragments. This change probably may reflect an increase of biomass production due to, amongst other things, warmer climatic conditions, which were shown by the occurrence of Pseudotsuga menziesii. With the absence of marine flooding events and an increased forest cover around the lake, the basin became more sheltered, resulting in the establishment of quiet water conditions. This environment may have promoted an increase in the lake productivity. The pollen record indicates that Nuphar was present in the lake at the end of the first interval, coinciding with this lithological change. Since Nuphar pollen is spread by insects, their presence indicates that Nuphar grew locally. The presence of Nymphaeaceae hairs indicates that 
Nuphar and perhaps Nymphaea inhabited the lake throughout the phase. Since Nuphar and Nymphaea inhabit shallow waters (Pojar and MacKinnon, 1994), their presence suggests a lowered water level in the basin. The declined water level might be a result of climatic warming, which is suggested by the occurrence of Pseudotsuga menziesii, but also of the fall in the relative sea level. In the lake, Filinia longiseta-type eggs, which represent the resting stages of the planktonic rotifer taxa Filinia longiseta and Filinia passa (Van Geel, 2001), occurred but vanished in the last third of this vegetation phase. These are regularly found in sediments of freshwater but also brackish waters (Van Geel, 2001). In the second interval, Potamogeton natans expanded in the lake. This species inhabits shallow to moderately deep (1-3 m), usually standing water under fresh to brackish conditions (Pojar and MacKinnon, 1994). The total pollen and spore concentrations increased during this phase, reflecting a lower sedimentation rate or an increased pollen and spore influx or both, which confirms the isolation of the lake from marine influence and an increased vegetation cover.

\section{Alnus-Picea-Pteridium aquilinum phase (PAZ WP-3, 220-155 cm)}

Another significant expansion of Alnus characterised this phase. Damp habitats may have prevailed around the lake, supporting the spreading of alder (cf. Klinka et al., 1989). Since alder forms the initial stage in successions (Klinka et al., 1989), an increased occurrence of this species might also indicate the presence of disturbed sites with e.g., exposed mineral soils in the area (cf. Klinka et al., 1989). During this period Picea became more abundant after a decline in the preceding phase. Other more shade- 
tolerant coniferous species such as Abies, Tsuga mertensiana and Tsuga heterophylla declined significantly in the vegetation around Woods Lake. This decline probably promoted the renewed expansion of the more shade-intolerant spruce on nutrient rich soils (cf. Klinka et al., 1989). However, relatively high percentage and concentration values of Tsuga heterophylla pollen suggest that Tsuga heterophylla still maintained an important portion in the forests around Woods Lake, even though this pollen type might be slightly over-represented in the pollen record (cf. Hebda, 1983). The decline of many coniferous species, especially the sub-alpine mountain hemlock, suggests that the climate during this phase became warmer and possibly drier (cf. Ritchie, 1987; cf. Pojar and MacKinnon, 1994). The pollen record suggests that this vegetation phase was characterised by a highly diverse vegetation cover. This is suggested by the fact that the total number of pollen and spore types is greatest in zone WP-3. Brown and Hebda (2003) describe a similar pattern of vegetation development during the early Holocene for southern Vancouver Island. This was characterised by a mosaic of open forests with more light-tolerant taxa on dry or disturbed sites and more closed forests of shadeintolerant taxa such as spruce and western hemlock on moist sites or both.

The expansion of herbaceous plants (e.g., Lysichiton americanum, Holodiscus discolor/Spirea) and ferns (e.g., Pteridium aquilinum), which started at the closure of the preceding phase, increased markedly. This suggests that more openings existed in the landscape, possibly as a result of fire disturbance (cf. Hebda, 1983) or drier climatic conditions. Skunk cabbage might have grown locally on open sites along the edge of the lake. Since pollen of Lysichiton americanum is distributed by insects, it is generally 
more poorly represented in the sediment record than pollen from wind dispersed taxa $(\mathrm{cf}$. Faegri and Iversen, 1989). Thus, relatively high values of Lysichiton americanum pollen suggest a local presence of this taxon. Skunk cabbage probably grew in the understorey of the alder stands, which formed around the lake (cf. Klinka et al., 1989). In contrast, warm and moist conditions have also been suggested for the early Holocene on the Queen Charlotte Islands as inferred from the presence of mixed forest stands of alder, spruce and western hemlock (Fedje, 1993). Brown (2000) proposed that an increase in Alnus pollen values might be related to relatively high local or regional fire incidence.

The first half of this vegetation phase was interrupted by a short interval, which was characterised by a significant expansion of Pseudotsuga menziesii. Since pollen ascribed to Pseudotsuga menziesii is often under-represented in the pollen spectra (cf. Hebda, 1983), attained values of Larix type pollen of $4 \%$ imply that Pseudotsuga menziesii formed an important portion of the vegetation around Woods Lake. At Bear Cove (northern Vancouver Island), a similar abrupt expansion of Pseudotsuga menziesii was dated at $8,800{ }^{14} \mathrm{C}$ years BP (Hebda, 1983). Unlike in other pollen diagrams where Pseudotsuga pollen decreases gradually (e.g., Mathewes, 1973, Hebda, 1983, Heusser, 1983), Larix type pollen disappears right after reaching maximum values. This may suggest a steep decline in Douglas-fir (Pseudotsuga menziesii) in the forest vegetation around Woods Lake, which is discussed below. The sudden spread of Pseudotsuga menziesii coincided with the decline of drought-intolerant taxa such as western hemlock, mountain hemlock and alder, suggesting drier and warmer conditions (cf. Mathewes, 1973, cf. Hebda, 1983). Warmer climatic conditions during the early Holocene are 
ascribed to a higher solar insolation, resulting in increased summer temperatures (Ritchie, 1987; Hallett et al., 2003).

The abrupt decline in Larix type pollen is followed immediately by a brief increase of the values of some arboreal pollen types (e.g., Tsuga mertensiana, Tsuga heterophylla pollen) and decrease of the values of some non-arboreal pollen types (e.g., Rosaceae, Lysichiton americanum pollen) and fern spores (e.g., Athyrium filix-femina spore), indicating a sudden expansion of trees and a decline in herbaceous taxa and ferns. The renewed spread of western hemlock and mountain hemlock probably indicates moister and cooler climatic conditions (cf. Hebda, 1983). Increasing frequencies of Potamogeton subg. potamogeton pollen and algal remains show the re-expansion of most likely Potamogeton natans and algae, probably suggesting wetter conditions.

Simultaneously, Lysichiton americanum declined possibly owing to an increased lake level, which might have caused its displacement to more distant areas from the coring site. These results may indicate that this warm and dry phase was interrupted by a short period with cooler and wetter conditions. Wetter conditions during a dry climate period were also observed at Cedar Swamp (Olympic Peninsula, northwestern Washington) and interpreted as the result of changes in the hydrology and climatic conditions (McLachlan and Brubaker, 1995). In the pollen diagrams, the inferred transition from drier to wetter conditions is marked by a very abrupt change in values of many pollen types such as Tsuga heterophylla, Tsuga mertensiana, Pinus undiff. and Alnus pollen within small sampling intervals, which may indicate a sedimentation gap (hiatus). Dry and warm climatic conditions or a decline in the relative sea level or both might have caused a 
lowering of the lake water level and thus an erosion of the sediments, leading to an interruption of the continuous pollen sequence (cf. Stolze, 2003). In contrast, the sediment and diatom records do not show obvious changes that may give evidence for a sedimentation gap (C. Doherty, personal communication, 2004).

The end of this early-Holocene vegetation phase is marked by minor expansion of Cupressaceae indicated by increased relative values of Cupressaceae pollen. The presence of Chamaecyparis/Thuja stomata suggests that yellow cedar or red cedar or both grew near the lake. Their expansion might suggest a climatic cooling and wetter conditions due to for example, an increased water table (cf. Klinka et al., 1989).

In this phase, aquatic taxa were abundant in the lake. Nuphar pollen and the presence of Nymphaeaceae hairs indicate that pond lily grew abundantly during this phase in the shallow open water of the lake (cf. Pojar and MacKinnon, 1994). The presence of Typha latifolia type pollen indicates most likely the occurrence of Typha latifolia in the first half of this phase. Nowadays, cattail grows in slow-flowing or quiet waters on lakeshores, marshes or ponds and finds its distribution limit south of the study area (Pojar and MacKinnon, 1994). The abundance of these shallow-water plants may reflect a decline in lake water level (cf. Janssen, 1967) possibly as a result of the drier climatic conditions and a fall in relative sea level. During the late Pleistocene and early Holocene, isostatic rebound caused a decline in relative sea level, whereas the eustatic rise was rather a subordinate factor that is not thought to have resulted in a rise in relative sea level in this region (Clague et al. 1982). The microfossil record shows that algal remains, mainly Pediastrum boryanum, Botryococcus and Spirogyra zygospores, were 
abundant throughout this phase, indicating freshwater conditions. Hystrichospheres (Dinoflagellate cysts) occurred at the end of this phase. Since most Dinoflagellates are marine species (Kuhry, 1985), a marine influence can be assumed. The increased relative sea level may have led to an increased water table and hence lake levels. Presumably, brackish conditions may have prevailed at the end of the phase, inferred from the coexistence of lacustrine and marine organisms. The sediment does not show changes that might reflect environmental changes. Sediments are composed of black organic gyttja, which reflects a high organic content, suggesting a high biomass production supported by the warm climatic conditions during this phase. High total pollen concentration values suggest a slow sedimentation and/or high pollen and spore influx in this phase.

\section{Cupressaceae-Alnus-Tsuga heterophylla-Picea phase (PAZ WP-4, 155-127.5 cm)}

The pollen record indicates a major expansion and abundance of Cupressaceae throughout this phase. The presence of Chamaecyparis/Thuja stomata indicates the extralocal occurrence of cedar. The presence of red cedar (Thuja plicata) rather than yellow-cedar (Chamaecyparis nootkatensis) is suggested by the occasional presence of Thuja stomata in the record. Shade-intolerant species such as alder, pine and spruce declined significantly in the vegetation, suggesting increased closure of the canopy and a decrease of e.g., fire disturbed sites around Woods Lake. Despite the spruce decline, the presence of Picea stomata indicates that this taxon was still present in close vicinity to the lake. Relatively high values of Tsuga heterophylla pollen (13\%) and the presence of 
Tsuga heterophylla stomata show that western hemlock probably played a major role in the vegetation around Woods Lake (cf. Hebda and Allen, 1993). Pollen of Larix type is continuously present, suggesting the occurrence of probably Pseudotsuga menziesii (cf. Pojar and MacKinnon, 1994). This taxon might have grown on dry or rocky sites, or areas influenced by fire (cf. Pojar and MacKinnon, 1994). Values of Abies pollen below $1 \%$ may suggest a regional occurrence of fir (Janssen, 1984) or a very sparse extralocal presence; however, the presence of Abies stomata indicates its extralocal occurrence. Herbaceous plants (e.g., Cyperaceae, Lysichiton americanum) and ferns (e.g., Pteridium aquilinum, Polypodium vulgare) decline in the vegetation during this phase, indicating a closing of the forest around Woods Lake. Presumably, a mixed coniferous forest dominated by Thuja/Chamaecyparis, Tsuga heterophylla and Picea became established around the lake. On southern Vancouver Island, the development of a forest of similar composition was ascribed to the mid-Holocene (Brown and Hebda, 2003). Alnus probably grew on wetter sites close to the lake or damp areas in the forest or coastal hinterland. This forest was similar in composition to the forest that existed at the end of the previous phase, whereas in this phase the portion of Cupressaceae increased and alder decreased. The appearance of Cupressaceae may indicate decreasing temperature or increasing precipitation or both (Pellatt and Mathewes, 1997). The presence of Pseudotsuga menziesii, however, suggests warmer and drier conditions than at present in the region (cf. Hebda, 1983). The concurrent occurrence of taxa, which indicate dry or moist conditions, may reflect the diverse presence of habitats around the lake, i.e. dry forest areas and damp sites around the lake and near the coast might have prevailed. 
Apart from that, a climatic transitional period with increased moisture and a slight temperature decline may be assumed (cf. Brown and Hebda, 2003).

As in the previous phase, this phase is characterised by the concurrent presence of aquatic taxa that may indicate lacustrine and possibly marine conditions, respectively. The occurrence of Nymphaeaceae hairs and Nuphar pollen indicates that pond lily grew in the lake vegetation, suggesting a freshwater environment (Klinka et al., 1989). Other freshwater indicators are algal remains of Spirogyra (Van Geel et al., 1989) and Botryococcus, which were present in this phase. Very high values of hystrichospheres indicate the spreading of Dinophyceae, suggesting salt-water penetration into the lake basin (cf. Kuhry, 1985). Black gyttja is still the corresponding sediment which changes towards the end of the phase into lighter coloured gyttja with coarse sand, small pebbles $(0.5-1 \mathrm{~cm})$ and occasionally wood fragments $(>2 \mathrm{~cm}$ in diameter $)$, indicating the input of allochthonous material probably due to marine inundation. The sediments do not suggest a fully marine environment. It is probable that only marginal or episodic penetration of seawater into the lake basin occurred, i.e. lagoon like conditions may have prevailed. The low values of the total pollen and spore concentration might indicate a high sedimentation rate and/or low pollen influx.

\section{Cupressaceae-Tsuga heterophylla- (Alnus) phase (PAZ WP-5, 127.5-0 cm)}

This phase is marked by another major expansion of cedar. Chamaecyparis/Thuja stomata and Cupressaceae pollen clumps indicate the extralocal presence of Chamaecyparis or Thuja or both throughout the phase. The separate identification of 
Chamaecyparis stomata and Thuja stomata shows that mainly Thuja grew near the lake. Since Cupressaceae pollen is generally poorly preserved (cf. Faegri and Iversen, 1989), high concentration values of this type most likely suggest an extralocal occurrence of Cupressaceae, confirming the above assumption. The increasing values of Cupressaceae pollen indicate a further increase in precipitation (cf. Pellatt and Mathewes, 1997). Low percentage and concentration values of pollen ascribed to the shade-intolerant taxa pine, alder and spruce may indicate a closed forest canopy (cf. Brown and Hebda, 2003). Even though Alnus pollen occurs in relative low frequencies in PAZ WP-5, the presence of Alnus pollen clumps in the upper part of this zone may suggest that alder grew near the lake in the last third of this phase. Consistently low values of Pinus undiff. pollen indicate that pine was present in the regional forest hinterland or transport from stunted individuals around the lake (cf. Wainman and Mathewes, 1987). Despite the low values of Pinus undiff. pollen, which suggest a regional pollen source (cf. Wainman and Mathewes, 1987), the presence of Pinus stomata indicates the nearby presence of pine in the early period of this phase. Similarly, the values of Abies pollen $(<1 \%)$ suggest a regional occurrence of the shade-tolerant fir, whereas the presence of Abies stomata indicates the occurrence of fir in close vicinity to the lake. The low values of Picea pollen $(<1 \%)$ suggest a limited regional occurrence of spruce. At the beginning of this phase a replacement of Picea by cedar might have occurred in the vegetation around Woods Lake. A similar event was dated at Bear Cove (northern Vancouver Island) at $3,000{ }^{14} \mathrm{C}$ years $\mathrm{BP}$ and considered to be a result of extensive humus accumulation, which provided moist substrates, favouring the growth of Cupressaceae (Hebda, 1983). Picea 
might have become restricted along rivers and the shore (Hebda, 1983). The presence of Picea stomata, however indicate that spruce must have grown locally. As discussed below, marine-flooding events occurred in the early stages of this vegetation phase, which might have also caused the decline in many tree species (e.g., Picea, Pinus). These inundations caused the input of allochthonous material into the lake basin; consequently the Picea stomata might have been introduced from secondary sources. During previous low stands of the relative sea level spruce might have inhabited sites close to the sea-shore (cf. Pojar and MacKinnon, 1994), which were flooded during this phase and plant remains transported and deposited into the lake. Hebda (1983) showed that Picea pollen is not abundant even at sites near shoreline Sitka spruce stands. A similar decrease in Picea pollen was found in the pollen record from Marion and Surprise Lake, southwestern British Columbia (Mathewes, 1973), Saanich Inlet, Vancouver Island (Heusser, 1983), Prince Rupert (Banner et al., 1983), and Two Frog Lake (J. Galloway, Ph.D. dissertation, Carleton University, in preparation) which is located about $10 \mathrm{~km}$ northwest of Woods Lake. Nowadays, spruce grows immediately adjacent to the lake; however, the pollen record does not reflect its extralocal occurrence. Spruce trees growing at Woods Lake are of tiny growth, indicating unfavourable growing conditions probably induced by damp, poorly drained soils (cf. Pojar and McKinnon, 1994). These conditions might cause low pollen production and consequently low pollen values. The low frequencies of Picea pollen might also be explained by the landward direction of the wind, causing the pollen to deposit in more remote areas. The continuous presence of 
Picea stomata in the lake sediments might also be a result of the run-off input from the steep slopes surrounding the lake (Figure 5-1).

The shade-intolerant western hemlock probably still played an important role in the vegetation around Woods Lake. The presence of Tsuga heterophylla stomata indicates the occurrence of the tree close to the lakeshore in the last third of the phase. Grains of Larix type pollen were not found, suggesting that Pseudotsuga menziesii had disappeared around Woods Lake, probably now totally replaced by Tsuga heterophylla (cf. Pojar and MacKinnon, 1994). The continuous occurrence of non-arboreal pollen such as Ericaceae type and Lysichiton americanum pollen and fern spores (e.g., Pteridium aquilinum, Athyrium filix-femina, Polypodium vulgare type spore) suggest that herbs and ferns were present throughout this phase. They probably formed parts of the understorey of the wet forest or occurred close to the lakeshore (cf. Klinka et al., 1989). In summary, the pollen record suggests a closed forest dominated by western hemlock and cedar (cf. Heusser, 1983). Similar vegetation was described for southern Vancouver Island and ascribed to the late Holocene (Brown and Hebda, 2003). Wet and mesothermal climatic conditions, similar to those which prevail in the region at present, can be inferred from the presence of western hemlock and cedar (cf. Mathewes, 1973).

The fluctuating levels of freshwater aquatic pollen, microforaminifera and hystrichospheres indicate that this phase was characterised by varying lake salinities. In the first half of this phase, hystrichospheres and microforaminifera occur, indicating that saltwater again penetrated the basin. Their decline and disappearance towards the last third of the phase suggests a decrease in salinity and change to freshwater conditions in 
the lake. Marine influence in the early part of this phase may be suggested by the absence of Nymphaeaceae hairs and Nuphar pollen throughout the main portion of the phase and their re-occurrence in the late part, indicating the absence and re-expansion of freshwater Nymphaeaceae species. Another indicator for freshwater conditions is the alga Botryococcus, which showed a major expansion in the late period. The total pollen concentration remains constant with relatively low values throughout most of the zone and increases remarkably at the end of the zone, perhaps suggesting a high sedimentation rate, which decreased in the later part of the phase. This change in sedimentation coincided with the shift from marine to lacustrine conditions. The change in the total pollen and spore concentrations might also be related to changes in the pollen source area. A falling relative sea level may have supported the expansion of plants in previously flooded areas around the lake and thus an increase in the pollen source area. Simultaneously with the change from marine to freshwater conditions, the coarse mineral content of the sediments decreased. In summary, these findings suggest that marine flooding events appear to have occurred in the first half of this phase, causing saline lake conditions, a higher sedimentation rate and an enrichment of coarse minerals in the lake sediments. 


\subsection{Summary of environmental changes}

\section{Paleoclimatic changes}

The early late glacial represented by the Pinus-Alnus-Tsuga mertensiana phase, is characterised by cool and moist conditions with lower temperatures and moisture than present. In the subsequent Alnus-Tsuga mertensiana-Pinus phase, which is assigned to the late late glacial, slightly warmer but still cool conditions and increased moisture prevail. Climate was cooler than present. This late late-glacial phase was interrupted by a short warmer and drier interval in the first half. Warmer and drier conditions relative to the previous phase and present conditions define the Alnus-Picea-Pteridium aquilinum phase, which represents the early Holocene. A short cool and moist interval in the early stage interrupted this warm and dry period. The mid-Holocene Cupressaceae-AlnusTsuga heterophylla-Picea phase represents a transitional interval with increased moisture and decreased temperatures relative to the preceding phase but with warmer and drier conditions than present. The Cupressaceae-Tsuga heterophylla-(Alnus) phase, representing the late Holocene, is defined by modern climate with cool and very moist conditions. A similar succession of the main climatic trends was inferred from the pollen record from Marion Lake, southern British Columbia (Mathewes, 1985).

\section{Relative sea level changes}

Marine conditions may have prevailed in the Woods Lake basin during the first half of the early late-glacial Pinus-Alnus-Tsuga mertensiana phase, indicating a high relative sea level in the Seymour Inlet complex. In the second half of this phase, brackish 
and subsequently freshwater conditions occurred in the basin, suggesting a fall in relative sea level and the isolation of the basin from the sea. Freshwater conditions prevailed throughout the late late-glacial Alnus-Tsuga mertensiana-Pinus phase and early-Holocene Alnus-Picea-Pteridium aquilinum phase. During the late Pleistocene and early Holocene, isostatic rebound caused a decline in relative sea level in this region (Clague et al. 1982). For the British Columbia mainland coast, Luternauer et al. (1989) suggest a rapid fall of relative sea level between 10,500 and 9,000 radiocarbon years BP due to an isostatic uplift, which was accompanied by crustal subsidence. At the end of the early-Holocene vegetation phase, brackish conditions possibly occurred in the basin due to increased relative sea level. During the mid-Holocene Cupressaceae-Alnus-Tsuga heterophyllaPicea phase, marginal or episodic penetration of seawater into the lake basin may have occurred, establishing lagoon like conditions. The sediment record suggests a possibly significant marine inundation due to an increased relative sea level at the end of this phase. In the mid-Holocene, this region was characterised by a relative sea level rise probably due to eustatic rise and forebulge collapse (Clague et al., 1982). The marine conditions prevailed throughout most of the late-Holocene Cupressaceae-Tsuga heterophylla-(Alnus) phase. In the last third of this phase, a change to freshwater conditions occurred in the basin, suggesting a decrease in relative sea level.

A summary of late Quaternary vegetation, climate and lake condition changes at the Woods Lake study site and inferred relative sea level changes gives Table 5-1. 


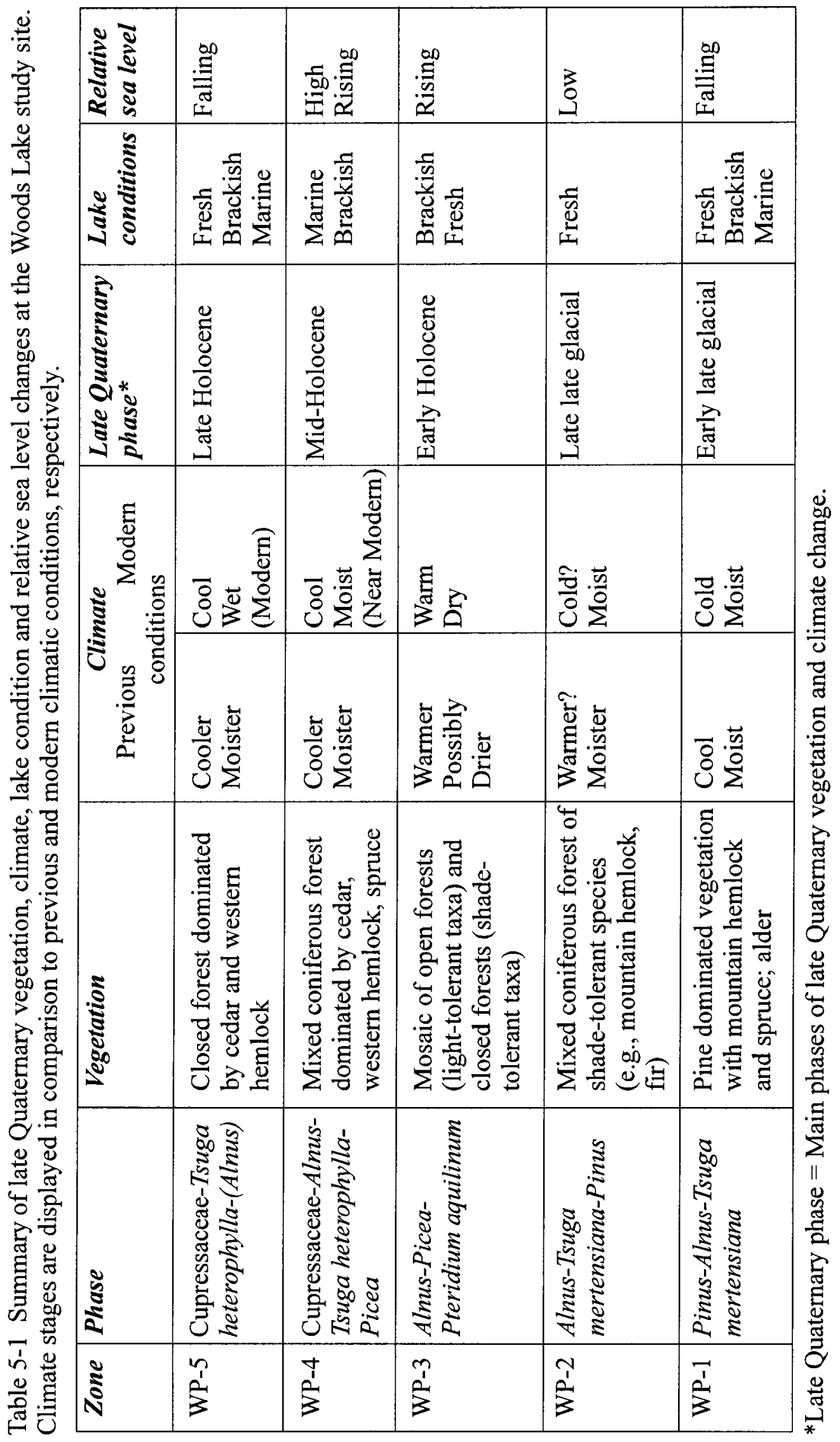




\subsection{Chronology}

Reliability of the radiocarbon dates

Three radiocarbon dates have been obtained from the Woods Lake core (Table 3-1). Comparison of these dates with radiocarbon dates available from other sites of coastal British Columbia allows an estimate to be made of the reliability of the dates.

In the Woods Lake diagram, the close of the early late-glacial Pinus - Alnus - Tsuga mertensiana phase is dated at $11,820 \pm 90{ }^{14} \mathrm{C}$ years BP. That seems to be reliable, since the end of similar vegetation phases is dated at $13,000{ }^{14} \mathrm{C}$ years $\mathrm{BP}$ for Vancouver Island (Hebda, 1995) and Queen Charlotte Island at $11,200{ }^{14} \mathrm{C}$ years BP (Fedje, 1993). At Woods Lake, the end of the mid-Holocene Cupressaceae-Alnus-Tsuga heterophyllaPicea phase is dated at $2,410 \pm 50{ }^{14} \mathrm{C}$ years BP. In the pollen records from Bear Cove, northern Vancouver Island (Hebda, 1983) and Marion Lake, southwestern British Columbia (Mathewes, 1973), the transition between two pollen zones similar to the transition between the PAZ's WP-4 and WP-5 were interpolated at $3,000{ }^{14} \mathrm{C}$ years BP, suggesting that the obtained date of $2,410 \pm 50{ }^{14} \mathrm{C}$ years BP for Woods Lake is slightly too young, since vegetation changes along the Pacific coast occurred often synchronously (Brown and Hebda, 2003).

At Woods Lake, the beginning of the second half of the late-Holocene CupressaceaeTsuga heterophylla-(Alnus) phase is dated at $12,300 \pm 90{ }^{14} \mathrm{C}$ years BP. This age appears to be too old. For southern Vancouver Island, a similar vegetation phase ranged from 5,000 to $0{ }^{14} \mathrm{C}$ years BP (Brown and Hebda, 2003). As shown, the Woods Lake basin was subject to restricted marine influence at this time, which may have resulted in the 
introduction of older carbon into the lake. Carbonate contamination from the local bedrock source is not apparent and contamination during sampling is unlikely $(\mathrm{C}$. Doherty, personal communication).

To ensure a better chronicle integration of environmental changes at the Woods Lake site, three additional samples from the Woods Lake sequence were submitted for AMS radiocarbon dating and presently the results are awaited.

\section{Additional radiocarbon dates from Seymour-Belize Inlet complex}

Since two of the three obtained radiocarbon dates appear to be unreliable, an adequate timing of the vegetation phases is not possible at present. More reliable radiocarbon dates are available from Two Frog Lake, which was investigated palynologically (J. Galloway, Ph.D. dissertation, Carleton University, in preparation). Two Frog Lake is located about $10 \mathrm{~km}$ northwest of Woods Lake at $51^{\circ} 06361^{\prime}, 127^{\circ} 32$ 082' (Figure 2-1) and occupies a slightly more elevated position above present sea level (sill height 4-5 m) than Woods Lake (J. Galloway, Ph.D. dissertation, in preparation).

The comparison of both the Woods Lake and Two Frog Lake diagram shows similar pollen assemblages, suggesting similar vegetation phases during the late Quaternary. The Two Frog Lake pollen record, however, does not cover completely the early late-glacial phase. The curves of Pinus undiff. and Picea pollen show very similar signals in both diagrams, indicating that these pollen derived mainly from regional sources. Regional signals in the curves of Cupressaceae, Tsuga heterophylla and Alnus pollen are less clear, indicating that these pollen types were mainly released from extralocal rather than 
regional sources. The difference in pollen spectra between the Woods Lake and Two Frog Lake record may also be a result of the different elevation above present sea level of both lakes. Since the Two Frog Lake basin is slightly more elevated, it does not appear to be reflooded by the sea after the initial isolation. Therefore, the pollen spectra, especially marine derived pollen inputs, might be different between the two lakes.

Due to the close proximity of the two study sites, it is assumed that the main palynological changes must have occurred simultaneously. Thus, for the purpose of discussion, the radiocarbon dates obtained from Two Frog Lake will be applied to the Woods Lake record. In the Two Frog Lake diagram, the decline of the relative values of Picea pollen and the beginning increase of the values of Tsuga heterophylla pollen is dated at $11,040 \pm 50{ }^{14} \mathrm{C}$ years BP. This event corresponds to the transition between the subzones WP-2a and WP-2b in the Woods Lake pollen diagram. The high abundance of Picea pollen at the end of zone WP-3, which corresponds to the Alnus-Picea-Pteridium aquilinum phase, can be observed in the Two Frog Lake diagram. This event is dated at $8,620 \pm 40{ }^{14} \mathrm{C}$ years BP. High values of Tsuga heterophylla pollen occur in the upper third of zone WP-5 $(17,97 \mathrm{~cm})$, which corresponds to the Cupressaceae-Tsuga heterophylla-(Alnus) phase. Similar pollen values can be found in the Two Frog Lake diagram, where the beginning of the increase in the frequency of Tsuga heterophylla pollen is dated at $2,210 \pm 40{ }^{14} \mathrm{C}$ years $\mathrm{BP}$. 


\subsection{Regional synthesis}

\section{Late glacial}

At Woods Lake, the transition between the early late-glacial Pinus-Alnus-Tsuga mertensiana phase and the late late-glacial Alnus-Tsuga mertensiana-Pinus phase is dated at $11,820 \pm 90{ }^{14} \mathrm{C}$ years $\mathrm{BP}$. A radiocarbon age to date the closing of the late late glacial is not available for the study site. This interval was dated on northern Vancouver Island from 11,500 to $10,000{ }^{14} \mathrm{C}$ years BP (Hebda, 1983), on southern Vancouver Island from 12,225 to $10,000{ }^{14} \mathrm{C}$ years BP (Brown and Hebda, 2003), and in the Lower Fraser River Canyon from 11,140 to $10,400{ }^{14} \mathrm{C}$ years BP (Rouse and Mathewes, 1975). At Saanich Inlet, a similar vegetation phase was ascribed to the earliest Holocene, which lasted from 11,450 to $10,350{ }^{14} \mathrm{C}$ years BP (Pellatt et al., 2001). In southern British Columbia, the start of the late late-glacial period was dated at about 11,800 years BP (Mathewes, 1985) which corresponds to the Woods Lake date. In general, these data show that the transition between the early late-glacial and the late late-glacial vegetation is relatively early at the study site.

Within the late late-glacial Alnus-Tsuga mertensiana-Pinus phase an expansion of western hemlock is dated at $11,040 \pm 50{ }^{14} \mathrm{C}$ years BP at Woods Lake. At Marion Lake, southern British Columbia, a similar sudden increase in Tsuga heterophylla pollen was dated at $10,000{ }^{14} \mathrm{C}$ years BP (Mathewes, 1985). These data show that the vegetation changes at Woods Lake occur relatively early in comparison to other sites on the British 
Columbia coast or they may imply that even the basal date is inaccurate due to e.g., carbon contamination.

\section{Early Holocene}

At Woods Lake, no data were available for the beginning of the early-Holocene Alnus-Picea-Pteridium aquilinum phase. The end of this vegetation phase was dated at about $8,620 \pm 40{ }^{14} \mathrm{C}$ years $\mathrm{BP}$. Similar vegetation phases are ascribed to the early Holocene and date on northern Vancouver Island from 9,000 to $7,000{ }^{14} \mathrm{C}$ years BP (Hebda, 1983), on southern Vancouver Island from 10,000 to $6,600{ }^{14} \mathrm{C}$ years BP (Brown and Hebda, 2003) and at Marion Lake 10,500 to $6,600{ }^{14} \mathrm{C}$ years BP (Mathewes, 1973). For Woods Lake, the radiocarbon date, which constrains the end of this phase, appears to be much too old.

\section{Mid-Holocene}

The onset of the Cupressaceae-Alnus-Tsuga heterophylla-Picea phase can be estimated at $8,620 \pm 40{ }^{14} \mathrm{C}$ years BP. The beginning of this phase is characterised by a first major expansion of Cupressaceae. This event was dated at Cape Bell, eastern Graham Island, at 5,500 ${ }^{14} \mathrm{C}$ years BP (Mathewes, 1985) and at Marion Lake at 6,600 ${ }^{14} \mathrm{C}$ years BP (Mathewes, 1973). For Woods Lake, no dates are available to date the end of this phase. A similar phase characterised by Tsuga heterophylla and Picea was dated on northern Vancouver Island from 7000 to $3000{ }^{14} \mathrm{C}$ years BP (Hebda, 1983) and on southern Vancouver Island from 6,600 to $4,400{ }^{14} \mathrm{C}$ years BP (Brown and Hebda, 2003), 
respectively. The $6,600{ }^{14} \mathrm{C}$ years $\mathrm{BP}$-datum coincides with the Mazama ash layer (Mathewes, 1985). This pyroclastic deposit, however, is found in coastal areas of British Columbia only on southern Vancouver Island and the south mainland coast (Clague, 1981) and does not appear to be present in the Woods Lake core. Transitional vegetation phases similar to the Cupressaceae-Alnus-Tsuga heterophylla-Picea phase were not recognised at some sites on the northwest Pacific coast (e.g., Rouse and Mathewes, 1975).

\section{Late Holocene}

For Woods Lake, no data are available to estimate the time range of the lateHolocene Cupressaceae-Tsuga heterophylla-(Alnus) phase. This phase is marked by a second major increase of Cupressaceae, which is dated at Bear Cove (northern Vancouver Island) at 3,000 ${ }^{14} \mathrm{C}$ years BP (Hebda, 1983), at Cape Bell (eastern Graham Island) after 3,000 ${ }^{14} \mathrm{C}$ years BP (Mathewes, 1985), at Marion Lake (southwestern British Columbia) at 3,000 ${ }^{14} \mathrm{C}$ years BP (Mathewes, 1973). For southern Vancouver Island, the beginning of the late Holocene is dated at $4,400{ }^{14} \mathrm{C}$ years BP (Brown and Hebda, 2003). For Woods Lake, a date of $2,210 \pm 40{ }^{14} \mathrm{C}$ years $\mathrm{BP}$ is available that marks a minor expansion of western hemlock in the last third of the Cupressaceae-Tsuga heterophylla(Alnus) phase. However, as discussed above, this date seems to be too old.

In spite of the problems imposed by the problematic dates, the Woods Lake sequence shows similar general vegetation and climatic patterns to other sites in coastal British Columbia (Table 5-2). The additional dates awaited may provide greater insights into the 
timing of the vegetation changes and facilitate more precise correlations with other regional pollen spectra. 
氠

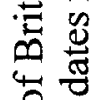

出政

등

8 㐘

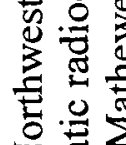

Z ․ㅣㅁ

ฮ

응 픈

2 2

\&

00

흥

过

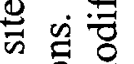

ฮี : 드

on

융

을.

๙

믕 응

틍

政

तै घ

๘ 9

con.0

을

응

है

可号

궝

E

के क्ष

$z=\bar{g}$

응

48

\begin{tabular}{|c|c|c|c|c|c|}
\hline 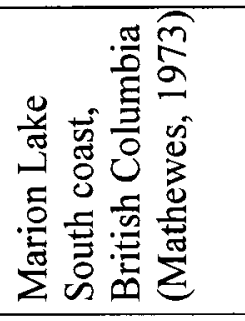 & 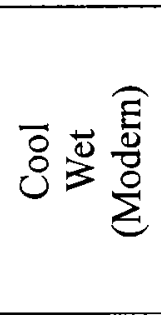 & 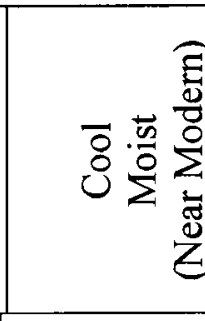 & & 焉忌 & $\frac{3}{0} \frac{\vec{n}}{0}$ \\
\hline 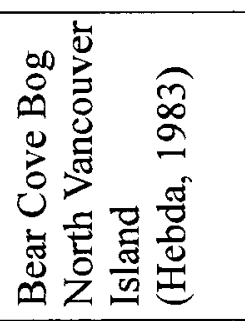 & 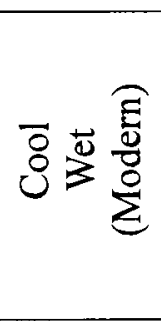 & 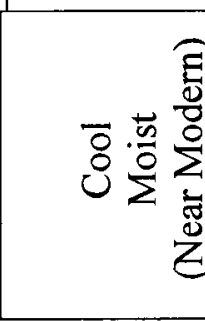 & & 焉 & $\frac{7}{8} \frac{\vec{n}}{0}$ \\
\hline 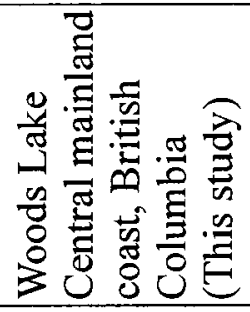 & $\overline{8} \frac{\widehat{\omega}}{\frac{\pi}{\delta}}$ & 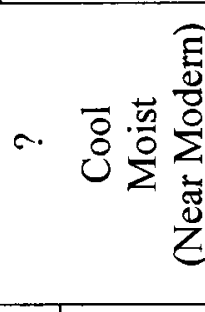 & \multicolumn{2}{|r|}{$\vec{a}$} & $\therefore \frac{\pi}{0} \frac{\vec{m}}{0}$ \\
\hline 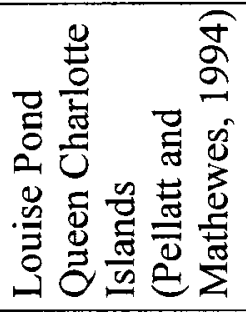 & $\overline{8} \frac{\widehat{E}}{3} \frac{\bar{d}}{8}$ & 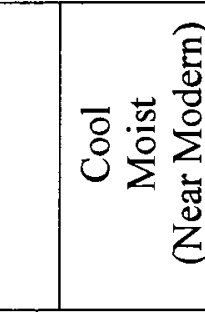 & $\frac{\bar{z}}{\Sigma} \cdot \frac{\vec{n}}{2}$ & है & $\underset{z}{\mathbb{z}}$ \\
\hline 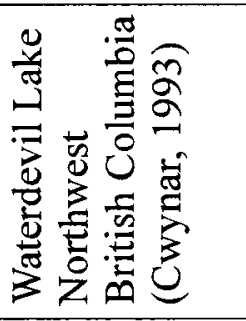 & 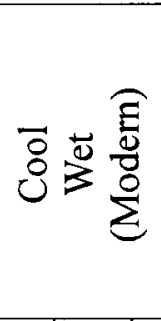 & 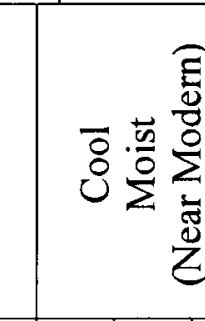 & \multicolumn{3}{|c|}{$\overleftrightarrow{\widetilde{z}}$} \\
\hline & $\begin{array}{ll}1 & 1 \\
8 & 8 \\
0 & 0 \\
& i\end{array}$ & 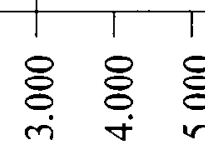 & $\begin{array}{ll}1 & 1 \\
8 & 8 \\
0 & 0 \\
0 & 0 \\
0\end{array}$ & $\begin{array}{ll} & 1 \\
0 & 8 \\
0 & 0 \\
\infty & 0 \\
\infty & 0\end{array}$ & $\begin{array}{lll} & \\
8 & 8 \\
0 & 0 & 0 \\
0 & 0 & 0\end{array}$ \\
\hline
\end{tabular}

o

.

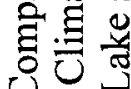

용

궁

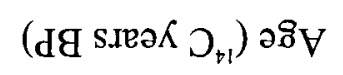

일

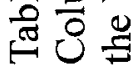




\section{Conclusion}

The recognised vegetation phases from the Woods Lake pollen record correspond to vegetation changes found at other sites in the Pacific Northwest region, confirming the assumption that the response of the vegetation to paleoclimatic changes occurred in a similar pattern in the Pacific Northwest region (Pellatt and Mathewes, 1997; Brown and Hebda, 2003). However, evidence for a warmer and drier interval in the cool late late glacial and a short interval with cooler and moister conditions in the warm and dry early Holocene was not found in other pollen records from the northwest Pacific coast. This shows that the Woods Lake pollen assemblages slightly differ from other regional spectra probably due to local sea level changes and associated changes in the pollen source area.

Due to the unreliability of some of the radiocarbon dates so far obtained, an exact chronicle integration of the recognised vegetation phases is currently not possible. Additionally submitted samples for radiocarbon dating will provide a better understanding of paleoenvironmental changes at the Woods Lake site.

The record of conifer stomata facilitates a more detailed reconstruction of the vegetation history around Woods Lake. Even though low values of tree pollen suggest a regional occurrence of the trees, the presence of stomata indicates their existence close to the lake. Identification of other palynomorphs such as algal remains further aids in the interpretation of environmental changes, showing marine inundations in the early late glacial and the late Holocene. 
In conclusion, accompanying analysis of non-pollen microfossils provided more detailed information on the local vegetation development and lake evolution, emphasizing the importance of combining pollen analysis with the analysis of other microfossils (cf. Lacourse et al., 2003). 


\section{$7 \quad$ References}

Banner, A., Pojar, J., Rouse, G.E., 1983. Postglacial paleoecology and successional relationships of a bog woodland near Prince Rupert, British Columbia. Canadian Journal of Forestry Research 13: 938-947.

Brown, K.J., 2000. Late-Quaternary vegetation, climate, fire history and GIS mapping of Holocene climates on southern Vancouver Island, British Columbia, Canada. Ph.D. Dissertation, University of Victoria, Victoria, British Columbia, Canada.

Brown, K.J., Hebda, R.J., 2003. Coastal rainforest connections disclosed through a Late Quaternary vegetation, climate, and fire history investigation from the Mountain Hemlock Zone on southern Vancouver Island, British Colombia, Canada. Review of Palaeobotany and Palynology 123: 247-269.

Burns, R.M., Honkala, B.H. (Tech. Coords.), 1990. Silvics of North America. Volume 1: Conifers. Agriculture Handbook 654. U.S. Department of Agriculture, Forest Service, Washington, D.C. Internet source:

http://www.na.fs.fed.us/spfo/pubs/silvics_manual/table_of_contents.htm 
Clague, J.J., 1981. Late Quaternary geology and geochronology of British Columbia. Part 2: Summary and discussion of radiocarbon-dated Quaternary history. Geological Survey of Canada Paper 80-35.

Clague, J.J., 1989. Quaternary geology of the Queen Charlotte Islands, pp. 65-74. In: Scudder, G.G.E., Gessler, N. (Eds.), The outer shores: based on the proceedings of the Queen Charlotte Islands First International Symposium, University of British Columbia, August 1984. $327 \mathrm{pp}$.

Clague J.J., Harper J.R., Hebda R.J., Howes, D.E., 1982. Late Quaternary sea levels and crustal movements, coastal British Columbia. Canadian Journal of Earth Sciences 19: $597-618$.

Cwynar, L.C., 1993. The abundance of exotic western hemlock pollen at Waterdevil Lake, White Pass, northern British Columbia: a preliminary analysis. Review of Palaeobotany and Palynology 79: 113-119.

Evans, M., 1996. Pollen evidence of late Holocene treeline fluctuation from the southern coast mountains, British Columbia. Géographie physique et Quaternaire 51: 81-92. 
Evitt, W.R., 1969. 18. Dinoflagellates and other organisms in palynological preparations, p.439-479, p1.18-1. In: Tschudy, R.T. and Scott, R.A. (Eds.), Aspects of Palynology. Wiley-Interscience, New York, U.S.A. 510 pp.

Faegri, K., Iversen, J., 1989. Textbook of pollen analysis. John Wiley and Sons, Chichester. 328 pp.

Fedje, D.W., 1993. Sea levels and prehistory in Gwaii Haanas. M.A. Thesis, Department of Archaeology, University of Calgary.

Grimm, E., 1987. CONISS: A Fortran 77 program for stratigraphically constrained cluster analysis by the method of incremental sum of squares. Computer and Geosciences 13: $13-35$.

Grimm, E., 1991. TILIA-GRAPH 2.0 version b.5 (computer software). Illinois State Museum, Research and Collections Centre, Springfield, Ill.

Grimm, E., 1993. TILIA 2.0 version b.4 (computer software). Illinois State Museum, Research and Collections Centre, Springfield, Ill.

Hallett, D.J., Lepofsky, D.S., Mathewes, R.W., Lertzman, K.P., 2003. 11000 years of fire history and climate in the mountain hemlock rain forests of southwestern British 
Columbia based on sedimentary charcoal. Canadian Journal of Forest Research 33: 292312.

Hansen, H.P., 1950. Pollen analysis of three bogs on Vancouver Island, Canada. Journal of Ecology 38: 270-276.

Havinga, A.J., 1984. A 20-year experimental investigation into the differential corrosion susceptibility of pollen and spores in various soil types. Pollen et Spores 26: 541-558.

Hebda, R.J., 1983. Late-glacial and postglacial vegetation history at Bear Cove Bog, northeast Vancouver Island, British Columbia. Canadian Journal of Botany 61: 31723192.

Hebda, R.J., 1995. British Columbia vegetation and climate history with focus on $6 \mathrm{ka}$ BP. Géographie physique et Quaternaire 49: 55-79.

Hebda, R.J., Allen, G.B., 1993. Modern pollen spectra from west central British Columbia. Canadian Journal of Botany 71: 1486-1495.

Hebda, R.J., Chinnappa, C.C., Smith, B.M., 1988. Pollen morphology of the Rosaceae of western Canada. II. Dryas, Fragaria, Holodiscus. Canadian Journal of Botany 66: 595612. 
Heusser, C.J., 1960. Late-Pleistocene environments of North Pacific North America. American Geographical Society, Special Publication No. 35. 308 pp.

Heusser, C.J., 1978. Palynology of Quaternary deposits of the lower Bogachiel River area, Olympic Peninsula, Washington. Canadian Journal of Earth Sciences 15: 15681578.

Heusser, C.J., 1985. Quaternary pollen records from the Pacific Northwest coast: Aleutians to the Oregon-California Boundary, pp. 141-165. In: Bryant, V.M., Holloway, R.G., (Eds.), Pollen records of Late-Quaternary North American sediments. American Association of Stratigraphic Palynologists Foundation, Dallas. 426 pp.

Heusser, L.E., 1983. Palynology and paleoecology of postglacial sediments in an anoxic basin, Saanich Inlet British Columbia. Canadian Journal of Earth Sciences 20: 873-885.

Howes, D.E., 1983. Late Quaternary sediments and geomorphic history of northern Vancouver Island, British Columbia. Canadian Journal of Earth Sciences 20: 57-65.

Janssen, C.R., 1966. Recent pollen spectra from the deciduous and coniferous-deciduous forest of northeastern Minnesota: a study in pollen dispersal. Ecology 47: 804-825. 
Janssen, C.R., 1967. A postglacial pollen diagram from a small Typha swamp. Ecological Monographs 37 (2): 145-172.

Janssen, C.R., 1984. Modern pollen assemblages and vegetation in the Myrtle Lake peatland, Minnesota. Ecological Monographs 54(2): 213-252.

Kapp, R.O., Davis, O.K., King, J.E., 2000. Pollen and spores. $2^{\text {nd }}$ edition, American Association of Stratigraphic Palynologists Foundation. 279 pp.

Klinka, K., Krajina, V.J., Ceska, A., Scagel, A.M., 1989. Indicator plants of coastal British Columbia. University of British Columbia Press, Vancouver. 288 pp.

Klinka, K., Quian, H., Pojar, J., Meidinger, D.V., 1996. Classification of natural forest communities of coastal British Columbia, Canada. Vegetatio 125: 149-168.

Komárek, J., Jankovská, V., 2001. Review of the green algal genus Pediastrum; implication for pollen-analytical research. Cramer, Berlin, Stuttgart, Bibliotheca Phycologica 108: 1-127.

Kuhry, P., 1985. Transgression of a raised bog across a coversand ridge originally covered with an Oak-Lime Forest. Paleoecological study of a Middle Holocene local 
vegetational succession in the Amsven (northwest Germany). Review of Palaeobotany and Palynology 44: 303-353.

Lacourse, T., Mathewes, R.W., Fedje, D.W., 2003. Paleoecology of late-glacial terrestrial deposits with in situ conifers from the submerged continental shelf of western Canada. Quaternary Research 60: 180-188.

Luternauer, J.L., Clague, J.J., Conway, K.W., Barrie, J.V., Blaise, B., Mathewes, R.W., 1989. Late Pleistocene terrestrial deposits on the continental shelf of western Canada: Evidence for rapid sea-level change at the end of the last glaciation. Geology 17: 357360.

MacDonald, G.M., 2001. Conifer stomata, pp. 33-47. In Smol, J.P., Birks, H.J.B., Last, W.M. (Eds.), Tracking environmental change using lake sediments. Volume 3:

Terrestrial, algal, and siliceous indicators. Kluwer Academic Publishers, Dordrecht. 371 pp.

Mathewes, R.W., 1973. A palynological study of postglacial vegetation changes in the University Research Forest, southwestern British Columbia. Canadian Journal of Botany 51:2085-2103. 
Mathewes, R.W., 1985. Paleobotanical evidence for climatic change in southern British Columbia during late-glacial and Holocene time, pp. 397-422. In Climatic change in Canada. 5. Critical periods in the Quaternary climatic history of northern North America. Syllogeus 55. 482 pp.

Mathewes, R.W., 1993. Evidence for Younger Dryas-Age cooling on the North Pacific Coast of America. Quaternary Science Reviews 12: 321-331.

Mathewes, R.W., Rouse, G.E., 1975. Palynology and paleoecology of early postglacial sediments from the lower Fraser River Canyon of British Columbia. Canadian Journal of Botany 59: 707-710.

Mathewes R.W., Heusser, L.E., 1981. A 12,000 year palynological record of temperature and precipitation trends in southwestern British Columbia. Canadian Journal of Botany 59: 707-710.

McAndrews, J.H., Berti, A.A., Norris, G., 1973. Key to the Quaternary pollen and spores of the Great Lakes Region. Life Sciences Miscellaneous Publications, Royal Ontario Museum. 59 pp. 
McLachlan, J.S., Brubaker, L.B., 1995. Local and regional vegetation change on the northeastern Olympic Peninsula during the Holocene. Canadian Journal of Botany 73: 1618-1627.

Meidinger, D.V., Pojar, J. (Eds.), 1991. Ecosystems of British Columbia. Research Branch, Ministry of Forests, Victoria, British Columbia. 330 pp.

Miller, M.M., Anderson, J.H., 1974. Out-of-phase Holocene climatic trends in the maritime and continental sectors of the Alaska-Canada Boundary Range, pp. 33- 58 In Mahaney, W.C. (Ed.), Quaternary Environments: Proceedings of a Symposium. Geographical Monographs 5, York University. 318 pp.

Moore, P.D., Webb, J.A., Collinson, M.E., 1991. Pollen Analysis. $2^{\text {nd }}$ ed. Blackwell, Cambridge. 216 pp.

Pals, J.P, Van Geel, B., Delfos, A., 1980. Paleoecological studies in the Klokkeweel Bog near Hoogkarspel (prov. of Noord-Holland). Review of Palaeobotany and Palynology 30: $371-418$.

Patterson, R.T., Guilbault, J.-P., Thomson, R.E., 2000. Oxygen level control on foraminiferal assemblage distribution in Effingham Inlet, Vancouver Island, British Columbia. Journal of Foraminiferal Research 30: 321-335. 
Patterson, R.T., Prokoph, A., Reinhardt, E.G., (submitted). Holocene cyclic climate variation in northern British Columbia. Palaeogeography, Palaeoclimatology, Palaeoecology.

Pellatt, M.G., Mathewes, R.W., 1997. Holocene tree line and climate change on the Queen Charlotte Islands, Canada. Quaternary Research 48: 88-99.

Pellatt, M.G., Hebda, R.J., Mathewes, R.W., 2001. High-resolution Holocene vegetation history and climate from Hole 1034B, ODP leg 169S, Saanich Inlet, Canada. Marine Geology 174: 211-226.

Pellatt, M.G., Mathewes, R.W., Walker, I.R., 1997. Pollen analysis and ordination of lake sediment-surface samples from coastal British Columbia, Canada. Canadian Journal of Botany 75: 799-814.

Pojar, J., Klinka, K., Demarchi, D.A., 1991. Chapter 6: Coastal Western Hemlock Zone, pp. 95-111. In Meidinger, D.V., Pojar, J. (Eds.), Ecosystems of British Columbia. Research Branch, Ministry of Forests, Victoria, British Columbia. 330 pp.

Pojar, J., MacKinnon, A. (Eds.), 1994. Plants of the Pacific Northwest coast: Washington, Oregon, British Columbia and Alaska. B.C. Ministry of Forests and Lone Pine Publishing, Victoria, British Columbia. 526 pp. 
Reille, M., 1990. Leçons de palynologie et d'analyse pollinique. Editions des du CNRS. Paris. $206 \mathrm{pp}$.

Richard, P., 1970. Atlas pollinique des arbres et de quelques arbustes indigènes du Québec. Naturaliste canadien. 97: 1-34, 97-161, 241-306.

Ritchie, J.C., 1987. Postglacial vegetation of Canada. Cambridge University Press, Cambridge. $178 \mathrm{pp}$.

Spooner, I.S., Hills, L.V., Osborn, G.D., 1997. Palynological reconstruction of late Quaternary palaeoclimate, Susie Lake, Boundary Ranges, Coast Mountains. Arctic and Alpine Research 29: 156-163.

Stockmarr, J., 1971. Tablets with spores used in absolute pollen analysis. Pollen et Spores 13: $615-621$.

Stolze, S., 2003. Holocene hiatus forming in the sediments of lake Melln. Abstract/Poster at the joint meeting of AASP-CAP-NAMS. October $5^{\text {th }}-8^{\text {th }}$. St. Catharines, Ontario, Canada.

Stuiver, M., Reimer, P.J., 1986. A computer program for radiocarbon age calibration. Radiocarbon 28, 1022-1030. 
Stuiver, M., Reimer, P.J., 1993. Extended ${ }^{14} \mathrm{C}$ database and revised CALIB radiocarbon calibration program. Radiocarbon 35: 215-230.

Stuiver, M., Reimer, P.J., Bard, E., Beck, J.W., Burr, G.S., Hughen, K.A., Kromer, B., McCormac, F.G., Plicht, J., Spurk, M., 1998a. INTCAL 98 Radiocarbon age calibration 24,000 - 0 cal BP. Radiocarbon 40: 1041-1083.

Stuiver, M, Reimer, P.J., Braziunas, T.F., 1998b. High-precision radiocarbon age calibration for terrestrial and marine samples. Radiocarbon 40: 1127-1151.

Van Geel, B., 2001. Non-pollen palynomorphs, pp. 99-119. In Smol, J.P., Birks, H.J.B., Last, W.M. (Eds.), Tracking environmental change using lake sediments. Volume 3: Terrestrial, algal, and siliceous indicators. Kluwer Academic Publishers, Dordrecht. 371 pp.

Van Geel, B., Coope, G.R., van der Hammen, T., 1989. Paleoecology and stratigraphy of the lateglacial type section at Usselo (The Netherlands). Review of Palaeobotany and Palynology 60: 25-129.

Wainman, N., Mathewes, R.W., 1987. Forest history of the last 12,000 years based on plant macrofossil analysis of sediment from Marion Lake, southwestern British Columbia. Canadian Journal of Botany 65: 2179-2187. 